\title{
Source, transport and impacts of a heavy dust event in the Yangtze River Delta, China, in 2011
}

\author{
X. Fu ${ }^{1, *}$, S. X. Wang ${ }^{1,2, *}$, Z. Cheng ${ }^{1}$, J. Xing ${ }^{1,3}$, B. Zhao ${ }^{1}$, J. D. Wang ${ }^{1}$, and J. M. Hao ${ }^{1,4}$ \\ ${ }^{1}$ State Key Joint Laboratory of Environment Simulation and Pollution Control, School of Environment, Tsinghua University, \\ Beijing 100084, China \\ ${ }^{2}$ State Environmental Protection Key Laboratory of Sources and Control of Air Pollution Complex, Beijing 100084, China \\ ${ }^{3}$ US Environmental Protection Agency, Research Triangle Park, NC, USA \\ ${ }^{4}$ Collaborative Innovation Center for Regional Environmental Quality, Tsinghua University, Beijing 100084, China \\ *These authors contributed equally to this work
}

Correspondence to: S. X. Wang (shxwang @tsinghua.edu.cn)

Received: 8 June 2013 - Published in Atmos. Chem. Phys. Discuss.: 20 August 2013

Revised: 18 December 2013 - Accepted: 26 December 2013 - Published: 3 February 2014

\begin{abstract}
Dust invasion is an important type of particle pollution in China. During 1 to 6 May in 2011, a dust event was observed in the Yangtze River Delta region (YRD). The highest $\mathrm{PM}_{10}$ (particles up to $10 \mu$ in diameter) concentration reached over $1000 \mu \mathrm{g} \mathrm{m}^{-3}$ and the visibility was below $3 \mathrm{~km}$. In this study, the Community Multi-scale Air Quality modeling system (CMAQ5.0) coupled with an in-line windblown dust model was used to simulate the formation, spatial and temporal characteristics of this dust event, and analyze its impacts. The threshold friction velocity for loose, finegrained soil with low surface roughness in the dust model was revised based on Chinese data to improve the model performance. This dust storm broke out in Xinjiang and Mongolia during 28 to 30 April and arrived in the YRD region on 1 May. The transported dust particles contributed to the mean surface layer concentrations of $\mathrm{PM}_{10}$ in the YRD region $78.9 \%$ during 1 to 6 May with their impact weakening from north to south due to the removal of dust particles along the path. The dry deposition, wet deposition and total deposition of $\mathrm{PM}_{10}$ in the YRD reached $184.7 \mathrm{kt}, 172.6 \mathrm{kt}$ and $357.32 \mathrm{kt}$, respectively. The dust particles also had significant impacts on optical/radiative characteristics by absorption and scattering. In Shanghai, the largest perturbations of aerosol optical depth (AOD) and irradiance were about $0.8 \mathrm{DU}$ and $-130 \mathrm{~W} \mathrm{~m}^{-2}$, which could obviously influence the radiation balance in this region. The decrease of actinic fluxes impacts future photochemistry. In Shanghai, the negative effects on the $\mathrm{NO}_{2}$ and $\mathrm{O}_{3}$ photolysis could be $-35 \%$ when dust parti-
\end{abstract}

cles arrived. The concentrations of $\mathrm{O}_{3}$ and $\mathrm{OH}$ were reduced by $1.5 \%$ and $3.1 \%$ in the whole of China, and by $9.4 \%$ and $12.1 \%$ in the YRD region, respectively. Such changes in $\mathrm{O}_{3}$ and $\mathrm{OH}$ levels can affect the future formation of secondary aerosols in the atmosphere by directly determining the oxidation rate of their precursors. The work of this manuscript is meaningful for understanding the dust emissions in China as well as for the application of CMAQ in Asia. It is also helpful for understanding the formation mechanism and impacts of dust pollution in the YRD.

\section{Introduction}

Mineral dust is the largest single contributor to particulate matter in the atmosphere (Forster et al., 2007; Rind et al., 2009). China is one of the regions that is usually affected by dust storms, especially in spring. The dust particles mainly originate from deserts in northern China and Mongolia (Zhang et al., 2003), which can reach Taiwan, southern China, Korea and even North America (Ault et al., 2011; Fan et al., 2013; Lin et al., 2012; Park et al., 2013). Suspended dust particles can be transported long distances as carriers and reaction sites of many harmful species, such as fungal spores, microorganisms and anthropogenic pollutants, including $\mathrm{NO}_{\mathrm{x}}$, VOC, and $\mathrm{Pb}$ (Huang et al., 2010; Lee et al., 2009). Some studies have shown that the number of people with lung inflammation or stroke increases significantly 
during a dust storm episode (Ichinose et al., 2008; Kang et al., 2013). It can also impact the radiation directly by absorption and scattering (Sokolik et al., 2001; Sun et al., 2012), and indirectly serve as cloud condensation nuclei (CCN) (Smoydzin et al., 2012; Solomos et al., 2012). Finally, dust particles can be removed by dry and wet depositions, which can take new nutrients into the surface water and may also result in acidification (Doney et al., 2007; Shi et al., 2012).

Numerical modeling is a useful method to analyze the characteristics of a dust event. In the recent decade, numerous physical- or empirical-based numerical models have been developed to describe the formation and transport of dust particles (e.g., Han et al., 2004; Wang et al., 2012a; Zender et al., 2003). They are usually implemented into air quality or climate models and used to analyze the impacts of dust particles on air quality, biogeochemical cycling, climate, and so on (Han et al., 2012; Wang et al., 2010a; Yan et al., 2012). The Community Multi-scale Air Quality modeling system (CMAQ) developed by the United States Environmental Protection Agency (US EPA) is one of the widely used air quality models (Knipping et al., 2006; Wang et al., 2010c; Wang et al., 2012b). Wang et al. (2012a) implemented an online dust emission and heterogeneous chemistry module into CMAQ version 4.7. Tong et al. (2011) developed a dust emission model called FENGSHA and used it to estimate the dust emission in the United States. Based on Tong's work, the dust model was coupled with the newest version of CMAQ (CMAQ5.0) and was officially released in February of 2012 (http://www.cmaq-model.org/). Up to now, this model has been used in the US only and its performance in other regions, especially in East Asia, still needs to be evaluated.

The Yangtze River Delta (YRD), located in the eastern part of China, is one of China's most developed and densely populated regions. This region covers $213340 \mathrm{~km}^{2}$, only about $2.22 \%$ of China's territory. However, highly populated metropolitan cities such as Shanghai, Nanjing, Suzhou, and Hangzhou are locate in the YRD. Therefore, it hosts $11.65 \%$ of the national population, produces $21.51 \%$ of China's GDP, consumes $16.57 \%$ of the nation's coal and bears $16.26 \%$ of the total vehicle population in 2010 (National Bureau of Statistics of China, 2011a; 2011b). Previous observations have indicated that long-range transport of dust particles may significantly contribute to the particulate pollution in Shanghai, the largest megacity in this area (Huang et al., 2010; Fu et al., 2010). Therefore, it is necessary to quantify the impacts of dust transport on regional air quality in the YRD region.

In this paper, we analyzed a strong dust event observed in the YRD region during 1 to 6 May of 2011 using the CMAQ5.0 with an in-line windblown dust model. In the next section, a detailed description of the model system is presented. Section 3 evaluates the model performance on meteorological conditions and pollutants concentration predictions. A further analysis of this dust event, including the dust emission characteristics, meteorological conditions, dust transport, and effects of dust on deposition and photochemistry, is presented in Sect. 4. Major findings and conclusions are summarized in Sect. 5.

\section{Model description}

\subsection{Simulation domain and episode}

One-way triple nesting simulation domains are used in this study, as shown in Fig. 1. They are based on the Lambert projection with the two true latitudes of $25^{\circ} \mathrm{N}$ and $40^{\circ} \mathrm{N}$. Domain 1 covers most of China with a grid resolution of $36 \mathrm{~km} \times 36 \mathrm{~km}$; domain 2 covers the eastern China with a grid resolution of $12 \mathrm{~km} \times 12 \mathrm{~km}$; domain 3 covers the Yangtze River Delta region with a grid resolution of $4 \mathrm{~km} \times 4 \mathrm{~km}$. From 1 May of 2011, an obvious increase of the particulate matter (PM) concentration in the YRD region was observed. The highest $\mathrm{PM}_{10}$ (particles up to $10 \mu$ in diameter) concentration reached over $1000 \mu \mathrm{g} \mathrm{m}^{-3}$ and the visibility decreased from above $10 \mathrm{~km}$ to below $3 \mathrm{~km}$. The $\mathrm{PM}_{2.5} / \mathrm{PM}_{10}$ ratio was only $25 \%$, which may be affected by the dust storm. Considering the transport of dust, the simulation episode chosen is from 28 April to 6 May in 2011.

\subsection{CMAQ model configurations and inputs}

The Community Multi-scale Air Quality modeling system version 5.0 (CMAQ5.0) with the updated 2005 carbon bond gas-phase mechanism (CB05) and the AERO6 aerosol module was applied in this study, which was officially released in February 2012. CB05 is enhanced by using the updated toluene chemistry (Whitten et al., 2010), modifying rate constants for $\mathrm{N}_{2} \mathrm{O}_{5}$ hydrolysis and adding reactions of xylene and toluene with chlorine radical. For the aerosol module, AERO6 reflects many new features and improvements over AERO5. The enhancements include splitting primary $\mathrm{PM}_{2.5}$ ((particles up to $2.5 \mu$ in diameter) emissions into 18 species, incorporation of ISORROPIAv2.1 (Fountoukis and Nenes, 2007), update of primary organic aerosol (POA) aging (Simon and Bhave, 2012), addition of a new in-line windblown dust model (Tong et al., 2011), and update of secondary organic aerosol (SOA) yield parameterization.

The Weather Research \& Forecasting Model (WRF) version 3.3.1 was used to generate the meteorological fields. The first guess fields were obtained from final operational global analysis data of the National Center for Environmental Prediction (NCEP). The Automated Data Processing (ADP) data were used in the analysis of four-dimensional data assimilation (FDDA). The physical options used in the WRF model were Morrison double-moment microphysics scheme (Morrison et al., 2009), the Rapid Radiative Transfer Model for GCMs (RRTMG) shortwave and longwave radiation scheme (Mlawer and Clough., 1998; Mlawer et al., 1997), Pleim-Xiu land surface scheme (Xiu and Pleim., 2001), ACM2 PBL 


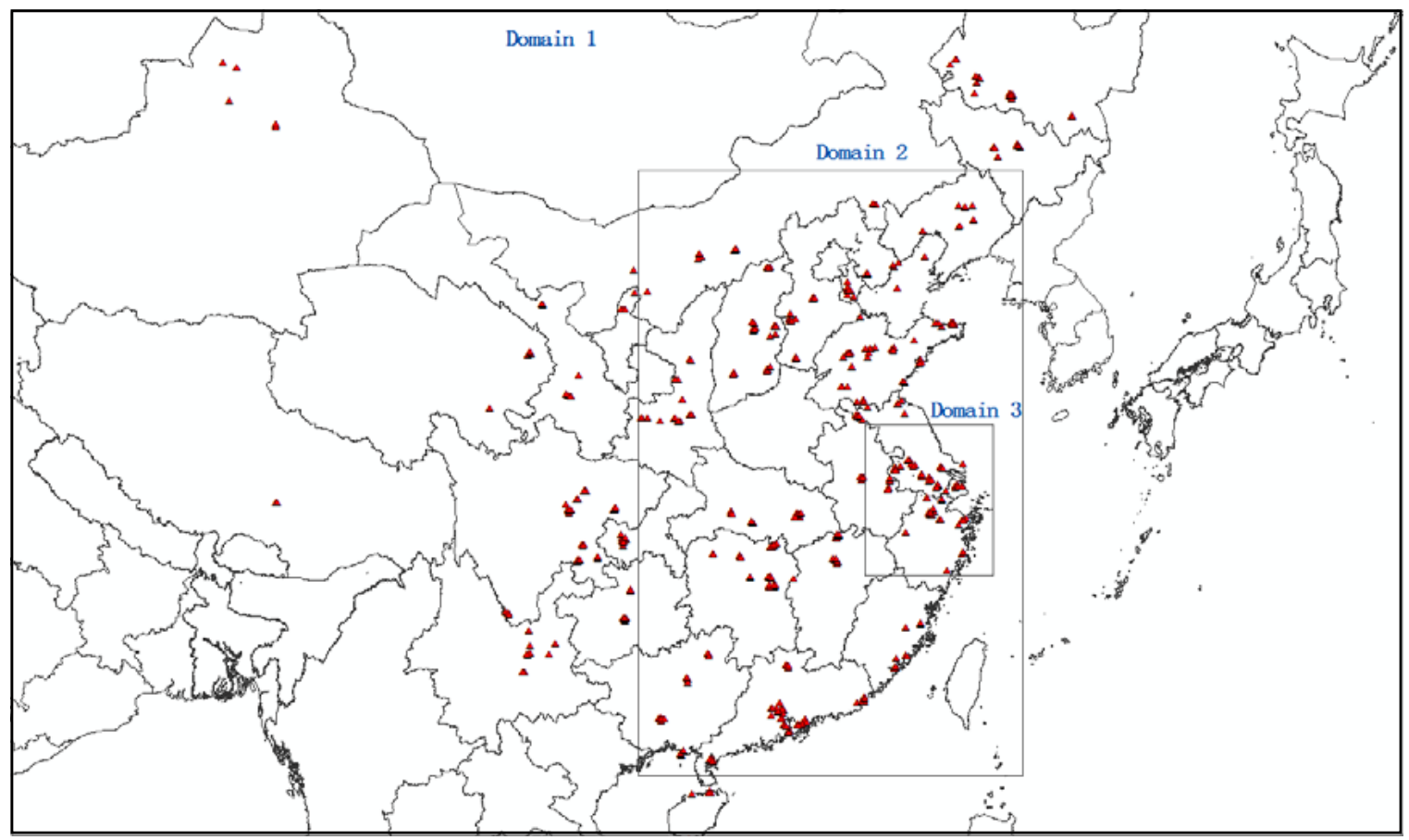

Fig. 1. Modeling domains and locations of the monitoring sites used for model evaluation. The red triangles indicate the 546 monitoring sites associated with the Ministry of Environmental Protection of China.

scheme (Pleim, 2007), and Kain-Fritsch cumulus scheme (Kain., 2004).

In this study, the anthropogenic emission inventory was developed based on the information provided by $\mathrm{Fu}$ et al. (2013), Zhao et al. (2013), and the Trace-P emissions (Streets et al., 2003). For the YRD region (including Jiangsu, Zhejiang and Shanghai), the data were mainly from Fu et al. (2013), which is with higher spatial resolution than the emission in Zhao et al and TRACE-P. For other provinces in China outside the YRD, the data were from Zhao et al. (2013). For other Asian countries, the TRACE-P data set was used. The biogenic emissions were calculated by the Model of Emissions of Gases and Aerosols from Nature (MEGAN) (Guenther et al., 2006). The total emissions for major pollutants (not including dust emissions) are listed in Table 1.

In order to evaluate the performance of the dust model and the impacts of dust emissions, three simulations are conducted in this study: DUST_DEFAULT, DUST_REVISED and DUST_OFF. As shown in Table 2, here DUST_DEFAULT means the situation where the dust model with officially released parameters is used. It is designed to evaluate the performance of the default dust model for this dust event. For DUST_REVISED, three parameters - friction velocity for loose, fine-grained soil with low surface roughness, and $\mathrm{PM}_{2.5} / \mathrm{PM}_{10}$ ratio - are chosen based on Chinese measurement data. In order to analyze the impacts of dust, the third simulation (DUST_OFF) is also con-
Table 1. The emissions of major pollutants for each domain during 28 April to 6 May.

\begin{tabular}{lllll}
\hline & Unit & Domain 1 & Domain 2 & Domain 3 \\
\hline $\mathrm{PM}_{10}$ & $10^{3} \mathrm{t}$ & 543.6 & 329.7 & 28.5 \\
$\mathrm{PM}_{2.5}$ & $10^{3} \mathrm{t}$ & 399.2 & 230.9 & 15.3 \\
$\mathrm{SO}_{2}$ & $10^{3} \mathrm{t}$ & 706.6 & 501 & 36.5 \\
$\mathrm{NO}_{\mathrm{x}}$ & $10^{3} \mathrm{t}$ & 571.5 & 395.7 & 56.4 \\
$\mathrm{NH}_{3}$ & $10^{3} \mathrm{t}$ & 432.7 & 276.1 & 30.1 \\
$\mathrm{VOC}$ & $10^{9} \mathrm{~mol}$ & 55 & 25.1 & 4 \\
\hline
\end{tabular}

ducted, which refers to the situation where the dust model is turned off.

\subsection{The in-line windblown dust model in CMAQ5.0}

The dust emissions were generated by the new in-line windblown dust model in CMAQ5.0 (Tong et al., 2011). The vertical flux $F\left(\mathrm{gm}^{-2} \mathrm{~s}^{-1}\right)$ was calculated by the following formula:

$F=\sum_{i, j} K \times A \times \frac{\rho}{g} \times S_{i} \times \operatorname{SEP} \times u_{*} \times\left(u_{*}^{2}-u_{* t i, j}^{2}\right)$ for $u_{*}>u_{* t}$,

where $i$ is the type of erodible lands, including shrub land, shrub grass and barren land; $j$ is the soil types. Different soil types have different fractions of clay, silt and sand; $K$ represents the ratio of vertical flux to horizontal sediment 
Table 2. Scenario design for model simulations.

\begin{tabular}{lll}
\hline Run Index & Model Configuration & Purpose \\
\hline DUST_DEFAULT & $\begin{array}{l}\text { The default parameters in the official version were used. } \\
\left(\text { e.g., } u_{* t i, j}^{\prime} \approx 0.7 \text { on average and } \mathrm{PM}_{2.5} / \mathrm{PM}_{10}=0.2\right)\end{array}$ & $\begin{array}{l}\text { Performance evaluation of } \\
\text { the default dust model }\end{array}$ \\
DUST_REVISED & $\begin{array}{l}\text { The threshold friction velocity for loose, fine-grained soil with low surface } \\
\text { roughness and } \mathrm{PM}_{2.5} / \mathrm{PM}_{10} \text { ratio are chosen based on Chinese data } \\
\left(u_{* t i, j}^{\prime} \approx 0.3 \text { and } \mathrm{PM}_{2.5} / \mathrm{PM}_{10}=0.1\right)\end{array}$ & $\begin{array}{l}\text { Performance evaluation of } \\
\text { the revised version }\end{array}$ \\
DUST_OFF & The dust model was turned off & Analysis of dust impacts \\
\hline
\end{tabular}

Table 3. Performance statistics of meteorological variables. See text for abbreviation definitions.

\begin{tabular}{|c|c|c|c|c|c|c|}
\hline & & & Domain 1 & Domain 2 & Domain 3 & Benchmark \\
\hline \multirow{6}{*}{$\begin{array}{l}\text { Wind speed } \\
\text { (WS10) }\end{array}$} & Mean OBS & $\left(\mathrm{m} \mathrm{s}^{-1}\right)$ & 3.53 & 3.26 & 3.50 & \\
\hline & Mean SIM & $\left(\mathrm{m} \mathrm{s}^{-1}\right)$ & 3.48 & 3.23 & 3.29 & \\
\hline & Bias & $\left(\mathrm{m} \mathrm{s}^{-1}\right)$ & -0.05 & -0.03 & -0.21 & $\leq \pm 0.5$ \\
\hline & $\mathrm{GE}$ & $\left(\mathrm{m} \mathrm{s}^{-1}\right)$ & 1.35 & 1.21 & 0.99 & $\leq 2$ \\
\hline & RMSE & $\left(\mathrm{m} \mathrm{s}^{-1}\right)$ & 1.82 & 1.69 & 1.35 & $\leq 2$ \\
\hline & IOA & & 0.82 & 0.80 & 0.83 & $\geq 0.6$ \\
\hline \multirow{4}{*}{$\begin{array}{l}\text { Wind direction } \\
\text { (WD10) }\end{array}$} & Mean OBS & (deg) & 231 & 195 & 129 & \\
\hline & Mean SIM & (deg) & 220 & 200 & 128 & \\
\hline & Bias & (deg) & 2.5 & 3.4 & 1 & $\leq \pm 10$ \\
\hline & GE & (deg) & 42 & 38 & 28 & $\leq 30$ \\
\hline \multirow{6}{*}{$\begin{array}{l}\text { Temperature } \\
\text { (T2) }\end{array}$} & Mean OBS & $(\mathrm{K})$ & 288.2 & 292.2 & 292.2 & \\
\hline & Mean SIM & $(\mathrm{K})$ & 286.3 & 291.4 & 290.8 & \\
\hline & Bias & $(\mathrm{K})$ & -1.9 & -0.8 & -1.4 & $\leq \pm 0.5$ \\
\hline & GE & $(\mathrm{K})$ & 2.9 & 2.0 & 2.3 & $\leq 2$ \\
\hline & RMSE & $(\mathrm{K})$ & 5.8 & 3.1 & 2.8 & \\
\hline & IOA & & 0.88 & 0.95 & 0.87 & $\geq 0.8$ \\
\hline \multirow{6}{*}{$\begin{array}{l}\text { Humidity } \\
(\mathrm{H} 2)\end{array}$} & Mean OBS & $\left(\mathrm{g} \mathrm{kg}^{-1}\right)$ & 6.88 & 10.13 & 9.63 & \\
\hline & Mean SIM & $\left(\mathrm{g} \mathrm{kg}^{-1}\right)$ & 6.95 & 10.12 & 9.11 & \\
\hline & Bias & $\left(\mathrm{g} \mathrm{kg}^{-1}\right)$ & 0.07 & -0.01 & -0.52 & $\leq \pm 1$ \\
\hline & GE & $\left(\mathrm{g} \mathrm{kg}^{-1}\right)$ & 1.42 & 1.76 & 1.41 & $\leq 2$ \\
\hline & RMSE & $\left(\mathrm{g} \mathrm{kg}^{-1}\right)$ & 13.93 & 11.69 & 1.95 & \\
\hline & IOA & & 0.31 & 0.63 & 0.66 & $\geq 0.6$ \\
\hline
\end{tabular}

flux, which is associated with the clay content (\%) and calculated by the following formula (Marticorena and Bergametti, 1995; Tong et al., 2011):

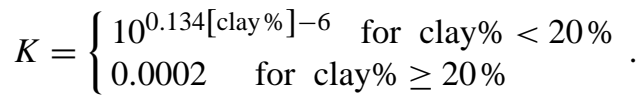

$A$ is the particle supply limitation; $\rho$ is the air density; $g$ is gravitational constant; and $S\left(\mathrm{~m}^{2}\right)$ is the area of dust source, which is based on the MODIS land use data. For the three erodible land types, it assumes that the fraction of erodible lands capable of emitting dust is $0.5,0.25$ and 0.75 , respectively; SEP is the soil erodibility factor, which is determined by the following formula:

$\mathrm{SEP}=0.08 \times$ clay $\%+1.00 \times$ silt $\%+0.12 \times$ sand $\%$.

$u_{*}\left(\mathrm{~m} \mathrm{~s}^{-1}\right)$ is the friction velocity, which directly comes from the output of WRF.
In this equation, $u_{* t}$ is the threshold friction velocity, which controls the intensity and the onset of dust emissions. It is expressed by $u_{* t i . j}=u_{* t i, j}^{\prime} \times f_{d i, j} \times f_{m i, j}$, considering the effects of surface roughness $\left(f_{d i, j}\right)$, soil moisture and snow cover $\left(f_{m i, j}\right) . u_{* t i, j}^{\prime}$ is the threshold friction velocity for loose, fine-grained soil with low surface roughness. The default value of $u_{* t i, j}^{\prime}$ is based on the measurement results of dust samples from the Mojave Desert in America (Gillette et al., 1980); the average value is 0.7 , which is used in the simulation of DUST_DEFAULT. For the simulation DUST_REVISED, the value 0.3 was chosen based on the measurement results of dust samples from the northern desert in China (Li et al., 2007). Besides the different default value, the $\mathrm{PM}_{2.5} / \mathrm{PM}_{10}$ ratio for dust emission was chosen as 0.1 (Niu et al., 2003; Wang et al., 2012a). For other parameters, the default values in the model were used. 
Table 4. Model performance for hourly $\mathrm{PM}_{10}$ concentrations. See text for abbreviation definitions.

\begin{tabular}{|c|c|c|c|c|}
\hline & & Domain 1 & Domain 2 & Domain 3 \\
\hline & Number of stations & 546 & 405 & 82 \\
\hline & Mean OBS $\left(\mu \mathrm{g} \mathrm{m}^{-3}\right)$ & 119 & 127 & 176 \\
\hline \multirow[t]{4}{*}{ DUST_OFF } & Mean SIM $\left(\mu \mathrm{g} \mathrm{m}^{-3}\right)$ & 63 & 79 & 49 \\
\hline & $\operatorname{Bias}\left(\mu \mathrm{g} \mathrm{m}^{-3}\right)$ & -56 & -48 & -127 \\
\hline & $\operatorname{NMB}(\%)$ & -47.1 & -37.8 & -72.2 \\
\hline & $R$ & 0.05 & 0.04 & 0.05 \\
\hline \multirow[t]{4}{*}{ DUST_DEFAULT } & Mean SIM $\left(\mu \mathrm{g} \mathrm{m}^{-3}\right)$ & 64 & 81 & 51 \\
\hline & $\operatorname{Bias}\left(\mu \mathrm{g} \mathrm{m}^{-3}\right)$ & -55 & -46 & -125 \\
\hline & $\operatorname{NMB}(\%)$ & -46.2 & -36.2 & -71 \\
\hline & $R$ & 0.07 & 0.06 & 0.13 \\
\hline \multirow[t]{4}{*}{ DUST_REVISED } & Mean SIM $\left(\mu \mathrm{g} \mathrm{m}^{-3}\right)$ & 106 & 136 & 152 \\
\hline & $\operatorname{Bias}\left(\mu \mathrm{g} \mathrm{m}^{-3}\right)$ & -13 & 9 & -24 \\
\hline & $\operatorname{NMB}(\%)$ & -10.9 & 7.1 & -13.6 \\
\hline & $R$ & 0.42 & 0.46 & 0.63 \\
\hline
\end{tabular}

\section{Model evaluation}

\subsection{Evaluation of meteorological simulations}

The accuracy of the meteorological prediction is the foundation of air quality simulation. Table 3 summarizes the statistical performance of $10 \mathrm{~m}$ wind speed and wind direction (WS10 and WD10, respectively), $2 \mathrm{~m}$ temperature (T2) and $2 \mathrm{~m}$ humidity (H2). Here, the simulated wind direction was calculated based on U-wind speeds (uu) and Vwind speeds $(\mathrm{vv})$. Its range is $0 \leq$ wind_direction $<360 \mathrm{de}-$ gree and it has a unique value. Hourly or every third hour observation data were obtained from the National Climatic Data Center (NCDC) for 1955 stations within domain 1, 787 stations within domain 2 and 90 stations within domain 3. The statistical parameters contain mean observation (Mean OBS), mean simulation (Mean SIM), bias, gross error (GE), root mean square error (RMSE), and the index of agreement (IOA), which are explained in detail in Baker (2004). The benchmark values are suggested by Emery et al. (2001), which are based on results of many studies in the US. These values are also used as reference standards in this study.

As shown in Table 3, the performance of WS10 is satisfactory. The bias, GE, RMSE and IOA values of all three domains are within the benchmark range. For WD10, while the biases are below 10 degrees, the gross errors are 2 to 21 degrees higher than the benchmark value. The high gross errors may have resulted from a caveat in treating the wind direction vector as a scalar in the calculation method, as described in previous studies (Wang et al., 2010b; Zhang et al., 2006). The T2 predictions are slightly underestimated, but the IOA values for all three domains are close to one, indicating an acceptable performance. The results for domain $1(36 \mathrm{~km}$ grid) are relatively worse, which mainly result from the poor representation of steep terrains with a coarse grid resolution (Wang et al., 2012a). For humidity, generally the model can reproduce the observed values. For domain 2 (12 km grid) and domain 3 (4 km grid), all statistical parameters are within the benchmark range. For domain 1 ( $36 \mathrm{~km}$ grid), the bias and GE values are above the benchmark, but the IOA value is a little lower. Because the benchmark values are mostly based on the domains with $4 \mathrm{~km}$ or $12 \mathrm{~km}$ resolution and the meteorological predictions can be more accurate than that for $36 \mathrm{~km}$, this slight underestimation is acceptable. Because the dust storm formation and transport are affected significantly by wind, we further compare wind speed and wind direction between observations and predictions at the 3 monitoring sites (see Fig. S1), which are in the source region, along the transport path and in the downwind region, respectively.

\subsection{Evaluation of chemical variables}

\subsubsection{Evaluation of pollutants concentration predictions}

Two observational data sets were used for model evaluation of pollutants concentration predictions. The first one was the hourly $\mathrm{PM}_{10}$ concentration for official monitoring sites in Mainland China obtained from the Ministry Environmental Protection of the People's Republic of China (MEP) (http: //113.108.142.147:20035/emcpublish/). Considering that the data from some monitoring sites were missing for the time period of this simulation episode, 546 monitoring sites (as shown in Fig. 1) were chosen for the model evaluation. the second data set was from the field measurements by Tsinghua University for 3 monitoring sites in the YRD region (as shown in Fig. 2), which were Shanghai, Nanjing in Jiangsu Province and Ningbo in Zhejiang Province.

Table 4 shows the hourly $\mathrm{PM}_{10}$ concentrations from observations and simulations DUST_OFF, DUST_DEFAULT 

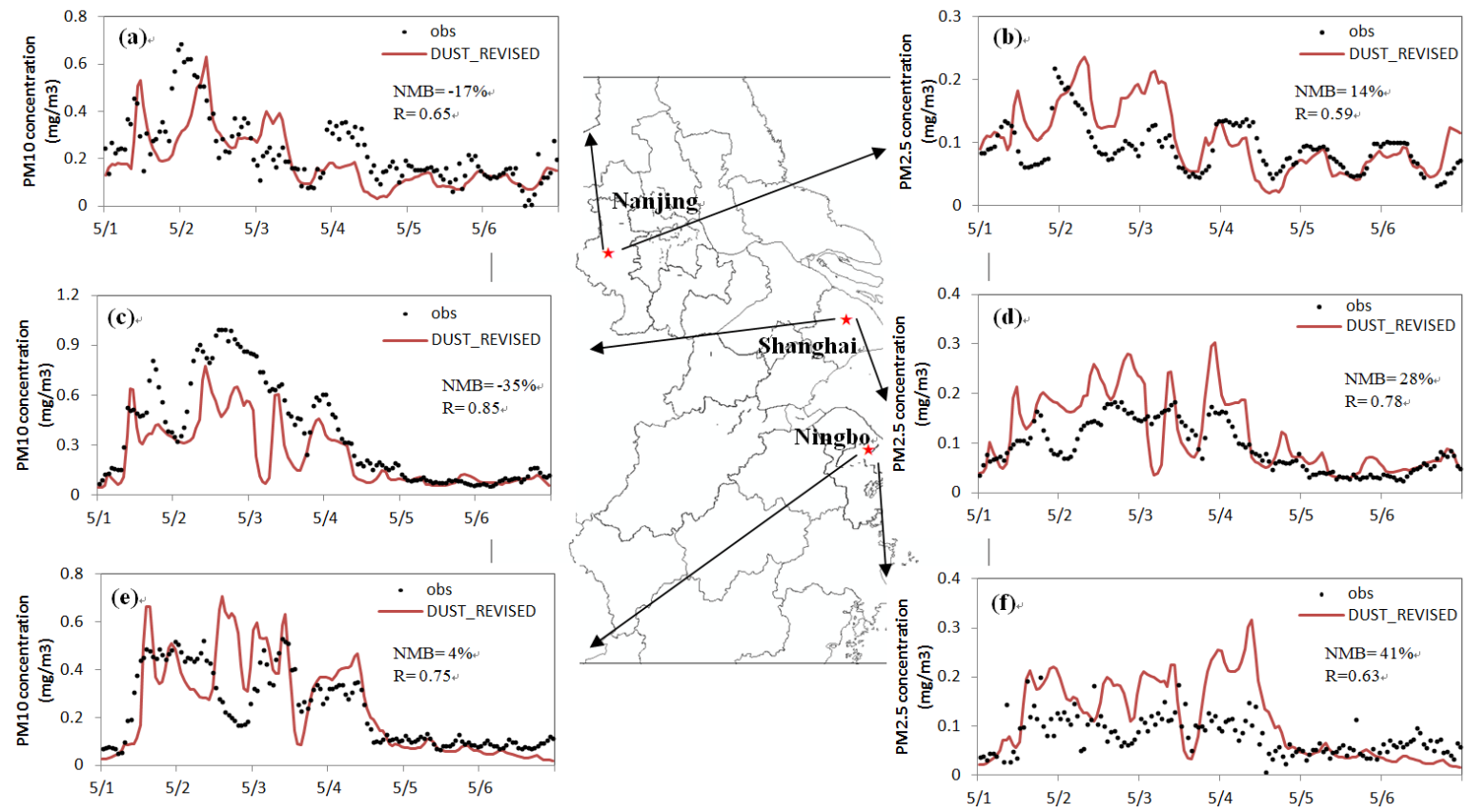

Fig. 2. Comparison of simulated $\mathrm{PM}_{10}$ concentrations $(\mathbf{a}, \mathbf{c}, \mathbf{e})$ and $\mathrm{PM}_{2.5}$ concentrations $(\mathbf{b}, \mathbf{d}, \mathbf{f})$ with observations at three sites in the YRD.

and DUST_REVISED for all 3 domains. The results of DUST_OFF underestimate the $\mathrm{PM}_{10}$ concentration significantly, with the normalized mean biases (NMBs) of $-47.1 \%,-37.8 \%$ and $-72.2 \%$ for domain 1 , 2 , and 3 , respectively. Compared with the results of DUST_OFF, the model performance of DUST_DEFAULT was not substantially improved. The model performance of DUST_REVISED is significantly improved compared with that of DUST_DEFAULT. The NMBs for domains 1, 2, and 3 are $-10.9 \%, 7.1 \%$ and $-13.6 \%$, respectively. The correlation coefficients $(R)$ are at the range of 0.4-0.6. Figure $\mathrm{S} 2$ shows the comparison of the spatial distribution for the $\mathrm{PM}_{10}$ concentrations. In general, the spatial distribution of the observations was consistent with the simulations, especially near the source region (e.g., 29 and 30 April). We can also see some overestimated cases at downwind regions. The possible reason is that the simulated results are average values for $36 \mathrm{~km}$ grid and it is difficult to capture the specific concentration for every point accurately for some time.

In order to test the model performance in terms of the ability to reproduce dust emission better, we compared $\mathrm{PM}_{10}$ concentrations between observations and predictions at the 3 sites near source region, which were Baotou in Inner Mongolia $\left(109.85^{\circ} \mathrm{E}, 40.68^{\circ} \mathrm{N}\right)$, Jinchang in Gansu $\left(102.19^{\circ} \mathrm{E}, 38.52^{\circ} \mathrm{N}\right)$ and Yinchuan in Ningxia $\left(106.17^{\circ} \mathrm{E}\right.$, $38.48^{\circ} \mathrm{N}$ ). The comparison of observed and simulated hourly $\mathrm{PM}_{10}$ concentration is shown in Fig. S3. Compared with DUST_DEFAULT and DUST_OFF, the model performance for DUST_REVISED is improved significantly. The respective NMBs for Baotou, Jinchang and Yinchuan are $-22.2 \%$,
$-38.6 \%$ and $-50.4 \%$, on average, during 28 April to 6 May. The $R$ values for these three sites are $0.77,0.66$ and 0.59 , respectively. The revised model can generally capture the dust outbreak event during 29 and 30 April.

In order to evaluate the performance of DUST_REVISED further, we compared the temporal variations of simulated hourly $\mathrm{PM}_{10}$ and $\mathrm{PM}_{2.5}$ concentrations with observations in 3 monitoring sites in the YRD region (as shown in Fig. 2). From 1 to 4 May, a strong dust event occurred in this region and the highest $\mathrm{PM}_{10}$ concentration could reach more than $1000 \mathrm{\mu g} \mathrm{m}^{-3}$. In general, the model could reproduce the temporal trends and high $\mathrm{PM}_{10}$ concentrations well. The NMBs of $\mathrm{PM}_{10}$ predictions for Nanjing, Shanghai and Ningbo are $-17 \%,-35 \%$ and $4 \%$, respectively, and the correlation coefficients $(R)$ are about $0.65-0.85$. Relatively large deviations occur at a few moments (e.g., early 2 May in Nanjing, early 3 May in Shanghai and midday 2 May in Ningbo), which may be the result of poor predictions of wind speed or wind directions at these moments. For example, for early May 3 in Shanghai, the simulated wind direction is 20 40 degrees, but the observed wind direction is $90-180$ degrees. On 3 May, dust particles were transported from sea to land and therefore this deviation of wind direction may have lead to the underestimation of PM in Shanghai. For the $\mathrm{PM}_{2.5}$ concentration, the model could reproduce its variation trend well and the correlation coefficients $(R)$ are about $0.6-0.8$. However, the model tends to overestimate the $\mathrm{PM}_{2.5}$ concentration slightly, with NMBs of $14 \%, 28 \%$ and $41 \%$ for Nanjing, Shanghai and Ningbo, respectively. This overestimation may be affected by the splitting between $\mathrm{PM}_{2.5}$ 

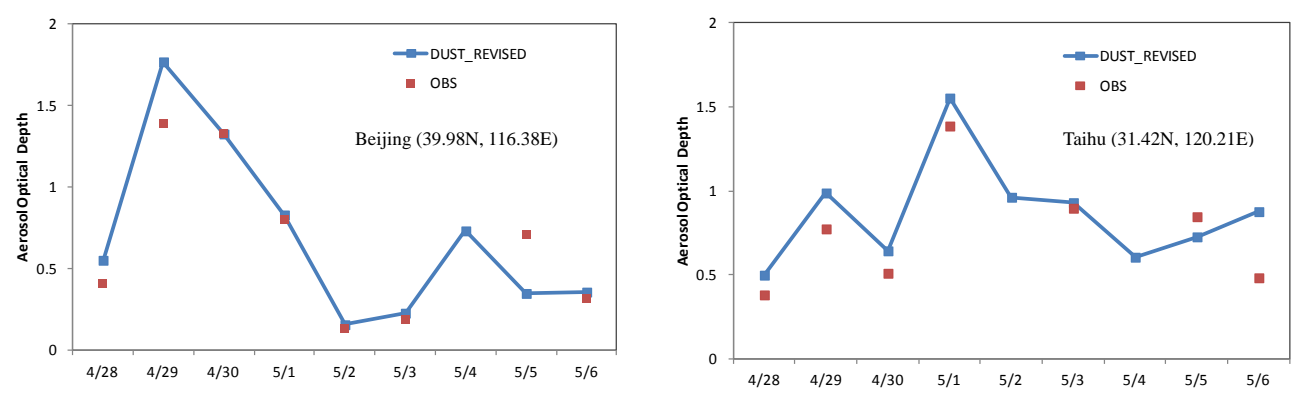

Fig. 3. Comparison of simulated daily average AOD with observations at two AERONET sites, 28 April to 6 May.

and $\mathrm{PM}_{2.5-10}$, because we just simply allocate $10 \%$ of dust $\mathrm{PM}_{10}$ emission to $\mathrm{PM}_{2.5}$. Nonetheless, the comparison results demonstrate that the CMAQ5.0 with the revised dust module could capture the PM variation reasonably well.

\subsubsection{Evaluation of aerosol optical depth (AOD) predictions}

Figure 3 compares the temporal variations of observed daily average AOD column from AERONET (Aerosol Robotic Network-an international federation of ground-based sun and sky scanning radiometer networks) and predictions from DUST_REVISED at two sites. The Beijing site $\left(116.38^{\circ} \mathrm{E}\right.$, $39.98^{\circ} \mathrm{N}$ ) is located at the transport path of dust and the Taihu site $\left(120.21^{\circ} \mathrm{E}, 31.42^{\circ} \mathrm{N}\right)$ is in the YRD region. The comparisons for the sites near the dust source region are not included because the measurement data at these sites are missing during this episode. As shown in Fig. 3, the simulated AOD agrees well with the observations. The NMBs for the Beijing and Taihu sites are $5.4 \%$ and $17.8 \%$, respectively. This demonstrates the ability of DUST_REVISED in capturing both the day-to-day variations of aerosols that include dust particles.

Figure S4 presents the daily averaged AOD distributions derived from simulation and retrieved from MODIS during the dust event. The comparison shows that the simulated AOD can generally catch the spatial distribution of satellite observations over eastern China.

\section{Results and discussion}

\subsection{Dust emission}

The simulation results of DUST_REVISED indicate that about $695 \mathrm{kt}$ dust particles $\left(\mathrm{PM}_{10}\right)$ were emitted in Xinjiang and Mongolia during 28 to 30 April 2011. Figures 4 and 5 show the spatiotemporal characteristic of dust emissions. On 28 April, a large amount of dust particles (about $145 \mathrm{kt}$ ) were generated in Xinjiang Province and southwestern Mongolia by the strong northwesterly wind. On 29 April, more new dust particles (about $515 \mathrm{kt}$ ) were emitted in south Mongolia and the highest density of dust emission could reach (a) 28 April 2011

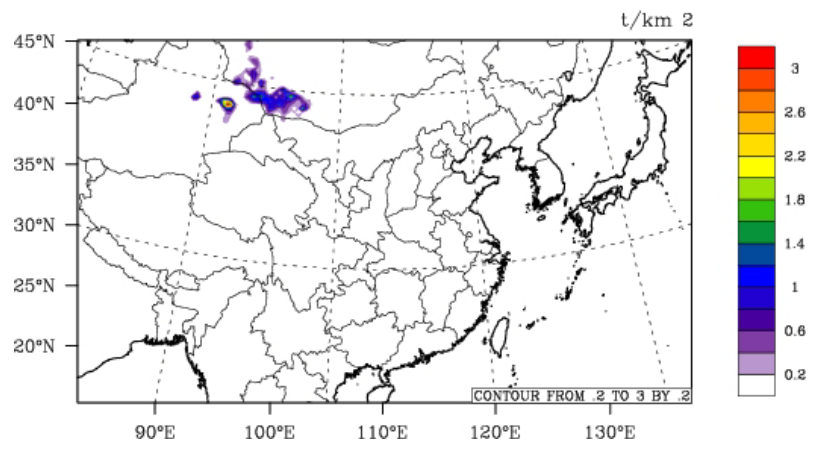

(b) 29 April 2011

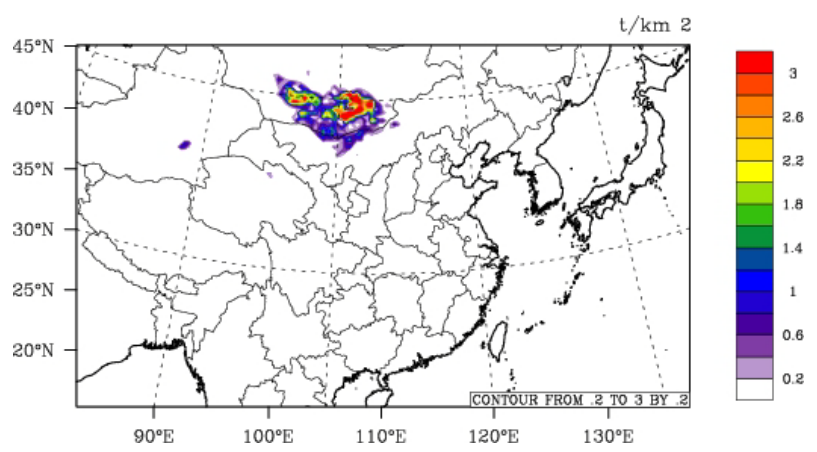

(c) 30 April 2011

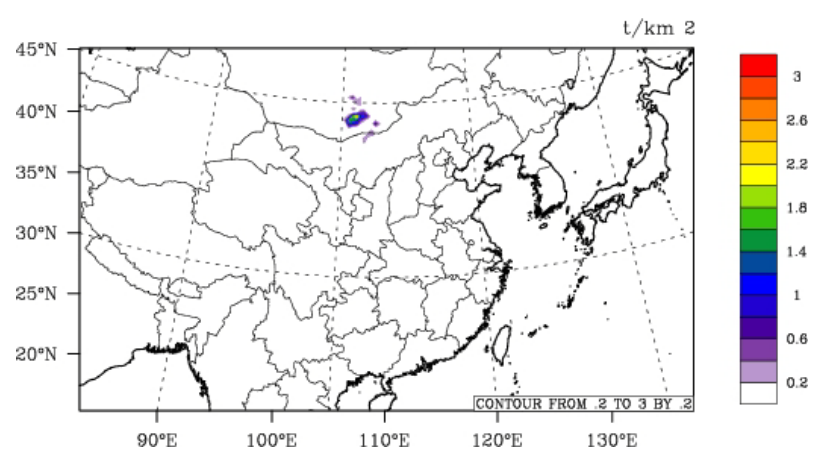

Fig. 4. Distribution of daily mean dust $\mathrm{PM}_{10}$ emissions by DUST_REVISED model. 


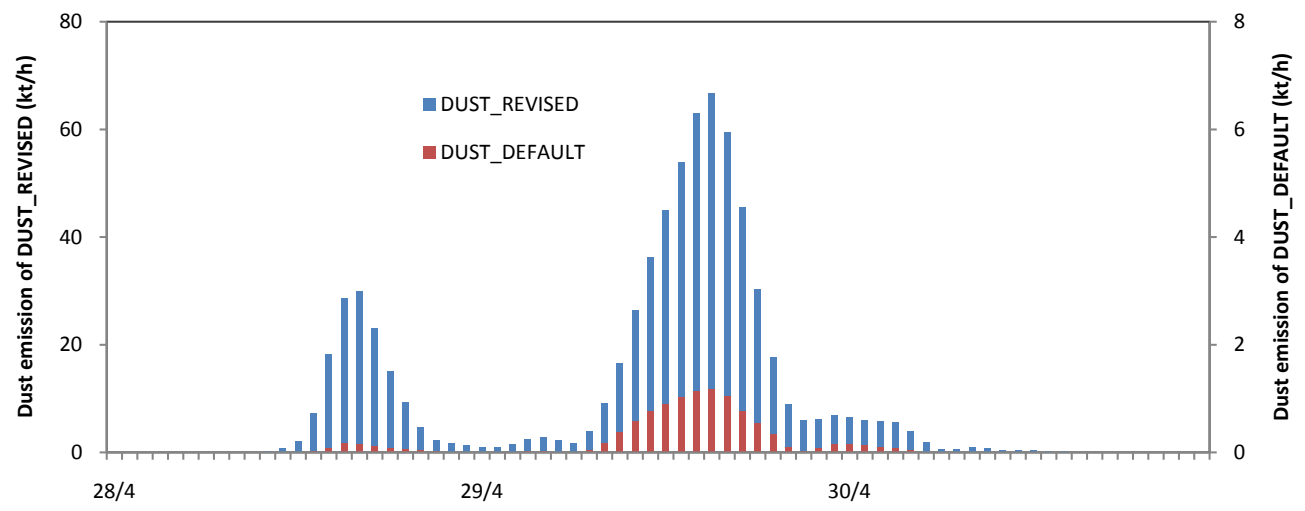

Fig. 5. The temporal variation of dust emissions.

above $7 \mathrm{t} \mathrm{km}^{-2}$. The largest value of total dust emission for the whole region occurred at 15:00 Beijing Time (BJT) on 29 April, about $66.8 \mathrm{kth}^{-1}$. Another small amount of dust particles were emitted on 30 April, only about $35 \mathrm{kt}$. As shown in Fig. 5, the predicted total dust emissions based on DUST_DEFAULT were only about $11 \mathrm{kt}$ and underestimated by $98 \%$ compared with that of DUST_REVISED. The default threshold friction velocity for loose, fine-grained soil with low surface roughness (about 0.7) was too high for Asian dust sources.

\subsection{Analysis of metrological condition for this dust event}

As shown in Fig. 6a, b, on 28 April, a cyclone was formed in Mongolia, associated with a cold front in the rear part of the low-pressure system. Strong surface winds $\left(8-14 \mathrm{~m} \mathrm{~s}^{-1}\right)$ occurred in eastern Xinjiang and western Mongolia, generating a dust storm there. On 29 April, the low-pressure cyclone developed further and moved east towards middle-southern Mongolia (as shown in Fig. 6c, d). The strong horizontal wind flow and the vertical flow caused the uplifting of dusts in this region. These possible locations of dust storms are in accordance with the satellite observations (http://www.temis.nl/airpollution/absaai/absaai-gome2a.

php?year=2011\&datatype=pics\&freq=daily). Due to the influence from the low pressure system, the high pressure associated with cold air arrived in the YRD region on 1 May (as shown in Fig. 6 e, f). From 1 May, the pressure and wind speed began to increase, and the temperature began to decrease. As shown in Fig. 7, the pressure in Shanghai increased from $1003.5 \mathrm{mb}$ on 1 May to $1016 \mathrm{mb}$ on 3 May, and the temperature decreased by 5-10 degrees Celsius. When the upper-level trough was leading the approach of cold air from north to south, dust particles also arrived in the YRD and the $\mathrm{PM}_{10}$ concentration in Shanghai increased from $74 \mu \mathrm{g} \mathrm{m}^{-3}$ to $800 \mu \mathrm{g} \mathrm{m}^{-3}$ on 1 May (as shown in Fig. 2). Controlled by high pressure, the wind became relatively light from midday 3 May, which is adverse to the dispersion of dust particles. The tail of the cold front passed over the YRD region at the end of 4 May. The temperature and wind speed began to increase, the pressure began to decrease.

\subsection{Dust transport and its impacts on $\mathbf{P M}_{10}$ concentration}

Figure 8 shows the spatiotemporal variation of $\mathrm{PM}_{10}$ concentration differences between DUST_REVISED and DUST_OFF, which helps to understand the transport of this dust event and the impacts of the dust storm on $\mathrm{PM}_{10}$ concentrations. The emitted dust particles mixed together and moved on in a southeastern direction. The $\mathrm{PM}_{10}$ concentrations at the sites near the dust sources, i.e., Lanzhou city in Gansu Province, reached nearly $5000 \mu \mathrm{g} \mathrm{m}^{-3}$. On 30 April, the dust began to affect eastern and central China. For example, the $\mathrm{PM}_{10}$ concentration in Tianjin increased from $50 \mu \mathrm{g} \mathrm{m}^{-3}$ to $1100 \mu \mathrm{g} \mathrm{m}^{-3}$. The dust band arrived in the YRD on 1 May and the $\mathrm{PM}_{10}$ concentration in Shanghai increased from $50 \mu \mathrm{g} \mathrm{m}^{-3}$ to $640 \mu \mathrm{g} \mathrm{m}^{-3}$ (as shown in Fig. 2). The maximum $\mathrm{PM}_{10}$ value reached $1000 \mu \mathrm{g} \mathrm{m}^{-3}$ on 2 May. Another part of the dust band also reached Korea and even Japan, but was blown back to the YRD by the southwestern wind on 3 May. This pathway of dust is similar to a dust storm observed in Shanghai in 2007 (Fu et al., 2011), which is one of the typical dust pathways that leads to heavily polluted days in the YRD due to dust transport. From 4 May, the impact of dust on the YRD region began to decline. By comparing the simulation results of DUST_REVISED and DUST_OFF, the contribution of the dust emissions to the mean surface layer concentrations of $\mathrm{PM}_{10}$ in the YRD region reached $78.9 \%$ during 1 to 6 May, with the impacts weakening from north to south due to the deposition of dust particles along the path. This contribution ratio is comparable with the ground measurements taken in Shanghai during a dust storm in 2009 , which reached $76.8 \%$ (Huang et al., 2012). 

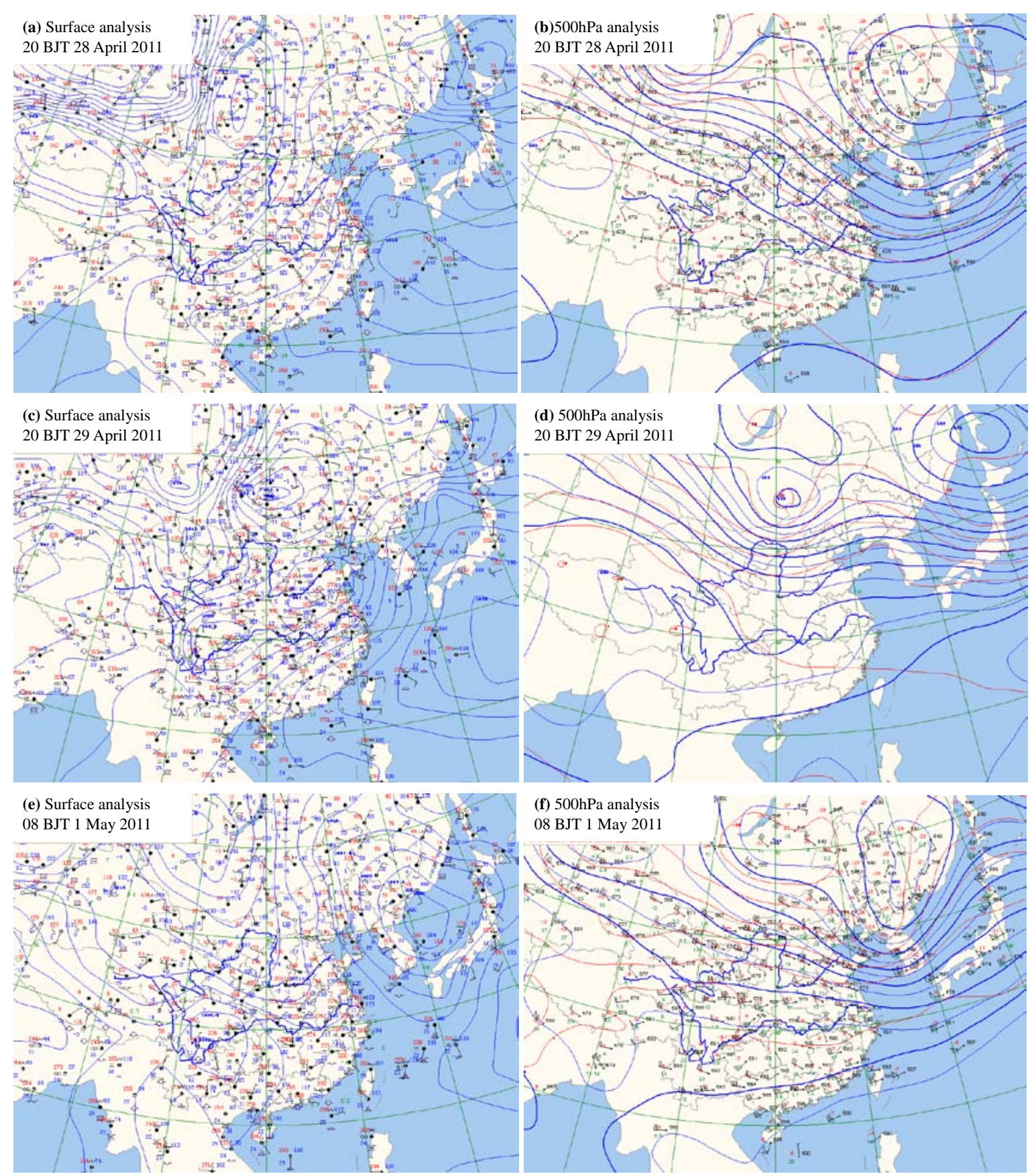

Fig. 6. Surface and $500 \mathrm{hPa}$ weather chart in China for 28 April (a, b), 29 April (c, d) and 1 May 2011 (e, f).

\subsection{Deposition of dust aerosols in the YRD region}

Dust particles can eventually be removed by both dry and wet depositions. During 1 to 6 May, the dry deposition, wet deposition and total deposition of $\mathrm{PM}_{10}$ were $184.7 \mathrm{kt}$, $172.6 \mathrm{kt}$ and $357.32 \mathrm{kt}$, respectively, of which $\mathrm{PM}_{2.5}$ depositions accounted for $5.7 \%, 36.4 \%$ and $20.5 \%$, respectively. Figure 9 shows the spatial distribution of dry deposition (DDEP), wet deposition (WDEP), total deposition (TDEP) and the difference (TDEP_DIFF) of total deposition between DUST_REVISED and DUST_OFF situations for $\mathrm{PM}_{10}$ in domain 3 (covering the YRD region) in these six days.

The dry depositions of $\mathrm{PM}_{10}$ accounted for $51.7 \%$ of the total. In general, the dry depositions in Jiangsu Province and Shanghai city were larger than that in Zhejiang Province, which was affected by the $\mathrm{PM}_{10}$ concentration. Dust particles were transported from north to south and the concentration became lower at the end of the transport path. 


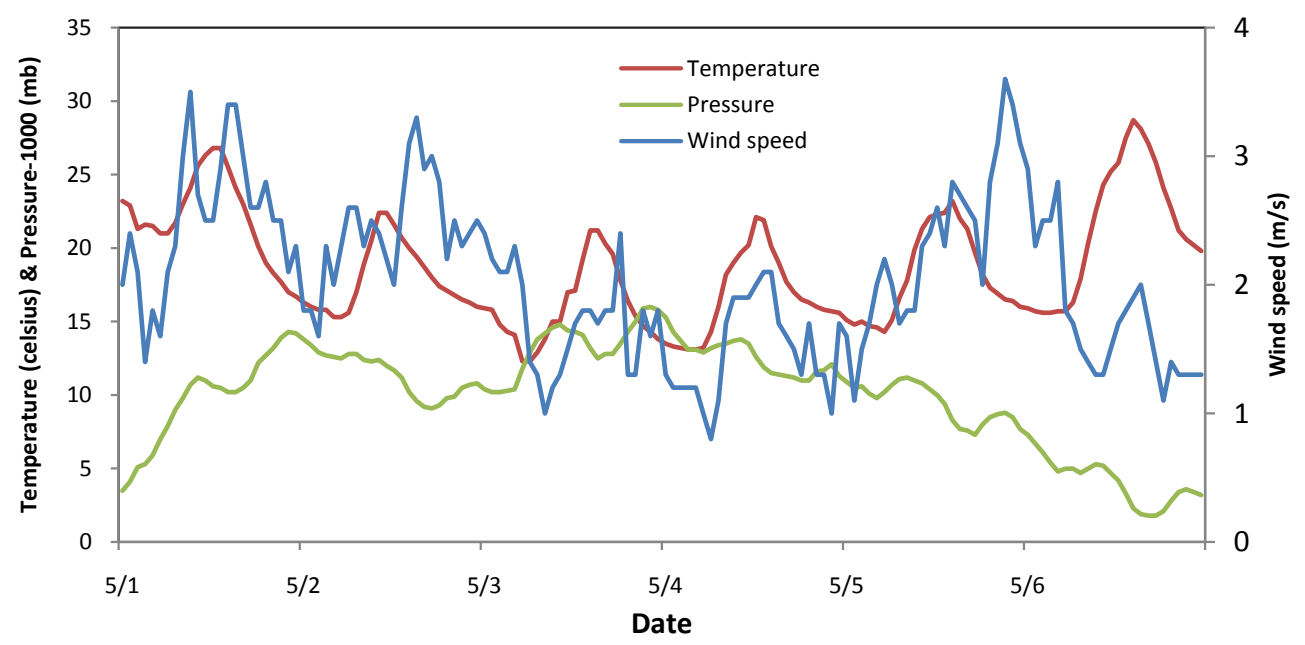

Fig. 7. Surface meteorological variables from 1 to 6 May in the Shanghai monitoring site.
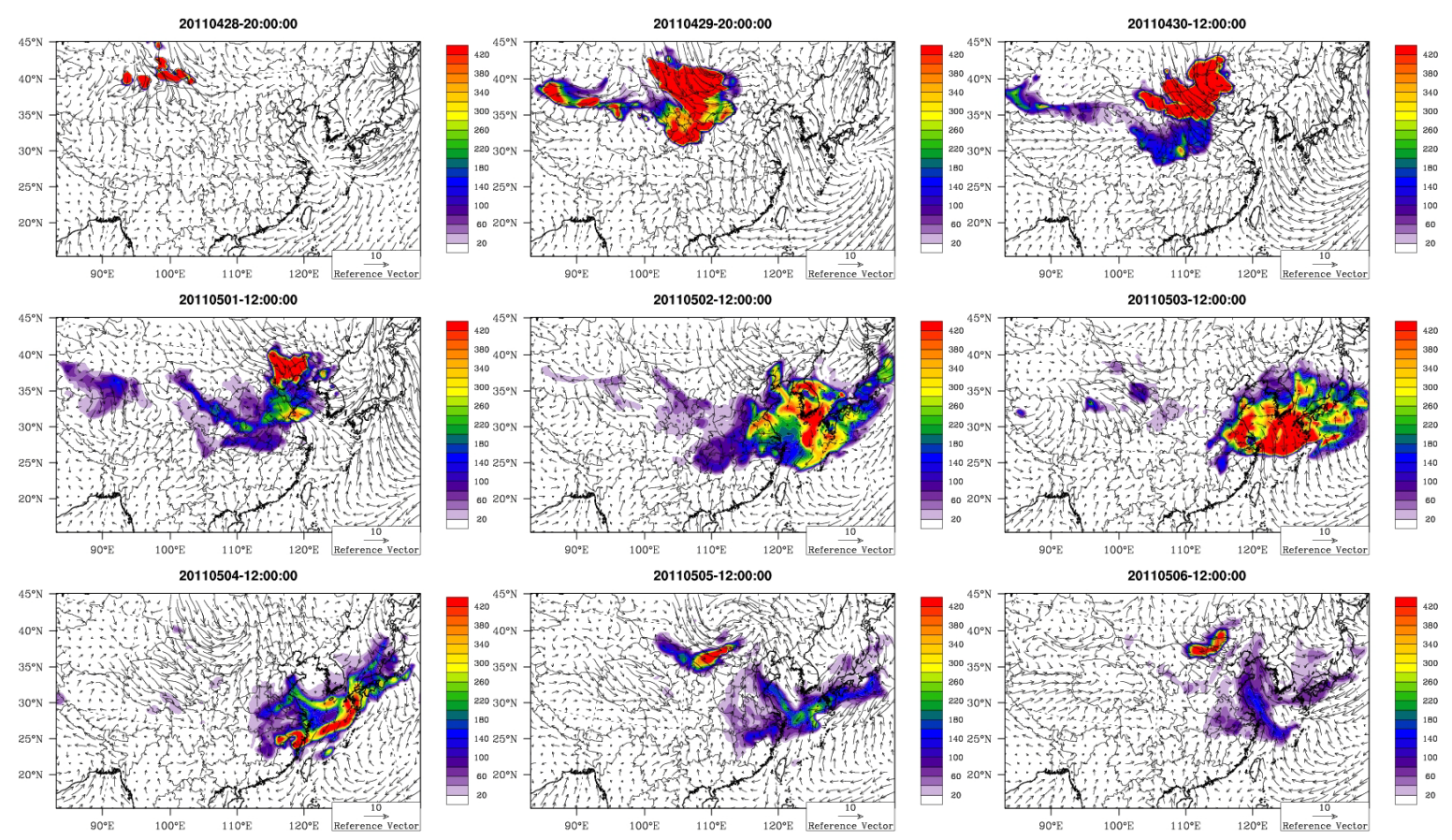

Fig. 8. The spatiotemporal variation of dust impacts on $\mathrm{PM}_{10}$ concentration $\left(\mu \mathrm{g} \mathrm{m}^{-3}\right)$ in the surface layer during this dust event (DUST_REVISED minus DUST_OFF).

Meanwhile, relatively high values can also be seen at some urban and forest regions. Besides the impacts of $\mathrm{PM}_{10}$ concentration, the larger associated parameters (e.g., the surface roughness length and leaf-area index) can lead to higher deposition velocity (Kumar et al., 2008; Fan et al., 2009). As shown in Fig. 9, wet depositions mainly occurred in the East China Sea, Shanghai, southern Zhejiang Province, etc. Besides the impacts of $\mathrm{PM}_{10}$ concentration, this distribution was related to the distribution of cloud and precipitation (shown as Fig. S5).
Comparison between the results of DUST_REVISED and DUST_OFF shows that the long-range transport of dust particles increased the total deposition of $\mathrm{PM}_{10}$ in the YRD by $1082 \%$, of which dry deposition increased by $2398 \%$ and wet deposition increased by $655 \%$. These deposited particles are very harmful because of their impacts on urban environment as well as on air quality and human health when resuspended in the atmosphere. Additionally, single particle analysis in previous literatures shows that dust particles are usually rich in N (Fu et al., 2012; Geng et al., 2009), which can contribute to nitrogen deposition. 
(a) DDEP

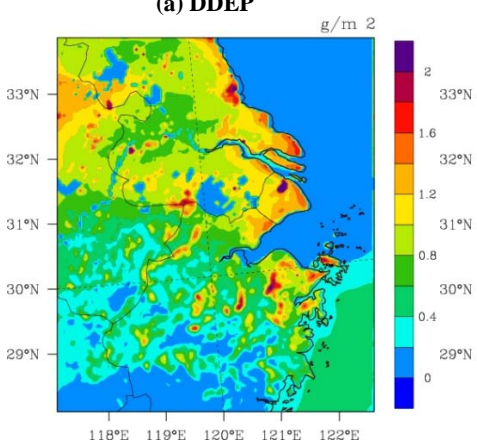

(b) WDEP

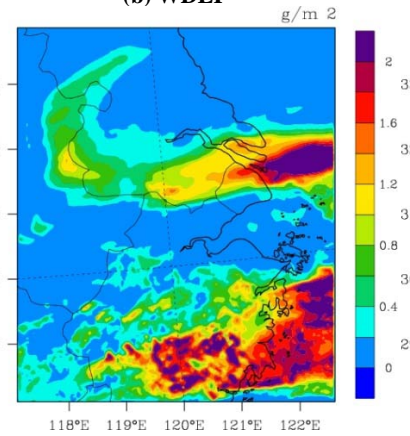

(c) TDEP

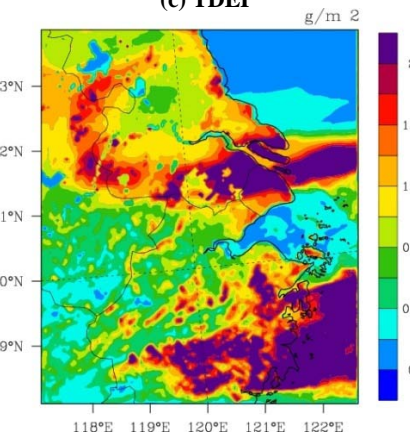

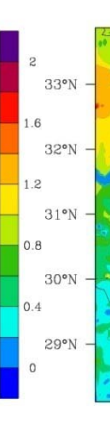

(d) TDEP_DIFF

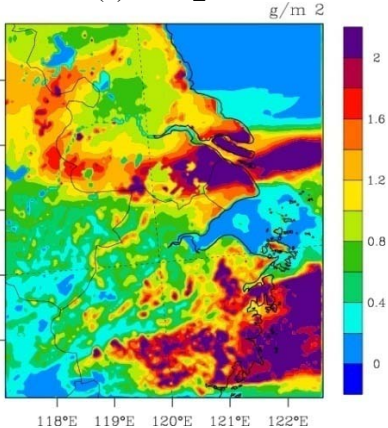

Fig. 9. The $\mathrm{PM}_{10}$ deposition in the YRD region from 1 to 6 May.

(a) Aerosol optical depth

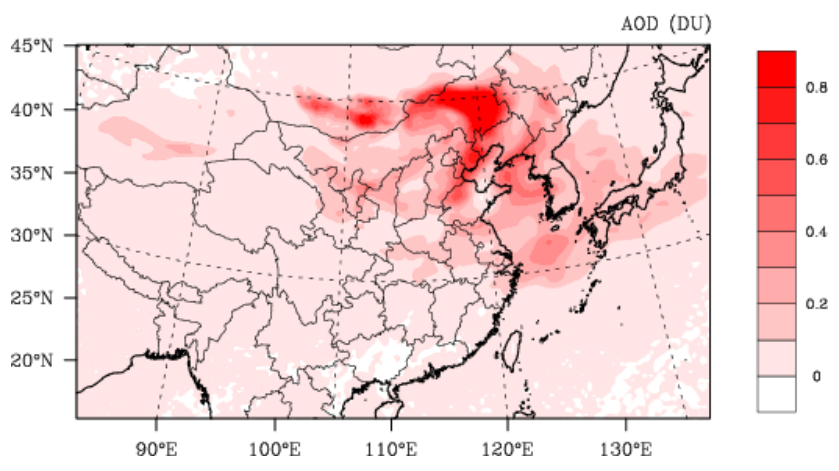

(b) The downward irradiance

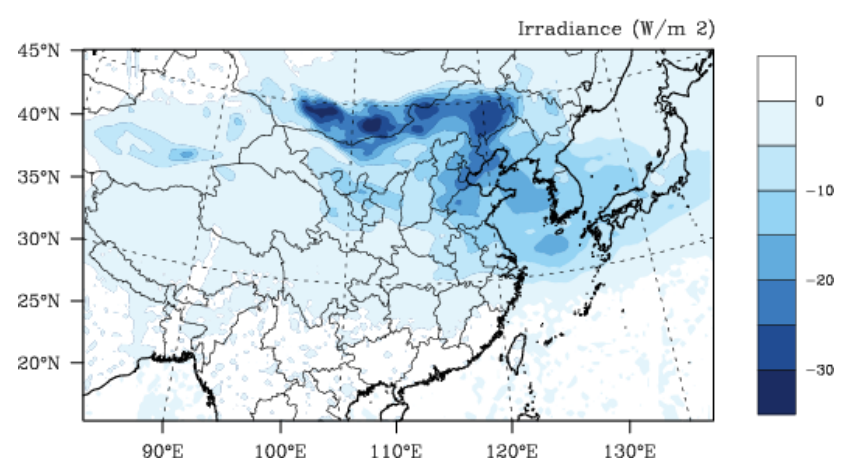

Fig. 10. The average differences of the aerosol optical depth (AOD) at $550 \mathrm{~nm}$ and downward irradiance simulated by DUST_REVISED and DUST_OFF, 28 April to 6 May.

\subsection{Impacts of dust storm on optical/radiative variables and photochemistry}

\subsubsection{Impacts on AOD and radiation}

Figure 10 presents the dust impact on aerosol optical depth (AOD) and irradiance, on average, during 28 April to 6 May. The average contribution of dust on AOD in the whole of China is $36.5 \%$. The high values of contribution occurred near the source region, about $1.3 \mathrm{DU}$ (above 90\%). The strong negative effects impacts on radiative forcing mainly concentrated over the source regions where heavy dust burden and large contributions to AOD from dust were measured, about -30 to $-20 \mathrm{~W} \mathrm{~m}^{-2}$, on average. The relatively low values of irradiance change, ranging from -20 to $-10 \mathrm{~W} \mathrm{~m}^{-2}$, could be found over the North China Plain and the China Sea. These values are similar to those of a previous study (Han et al., 2012). The hourly averaged simulation results showed that in Shanghai, the largest perturbations of AOD and irradiance were about $0.8 \mathrm{DU}$ and $-130 \mathrm{~W} \mathrm{~m}^{-2}$, which could obviously influence the radiation balance in this region.

\subsubsection{Impacts on photochemistry}

\section{Photolysis rates}

Dust particles have important effects on photolysis rates (Bian and Zender, 2003; Ying et al., 2011). Photolysis rates $\left(\min ^{-1}\right)$, also called $J$-values, have been computed for a chemical species $w$ by (Philip, 2000):

$J_{w}=\int_{\lambda_{1}}^{\lambda_{2}} F(\lambda) \sigma_{i}(\lambda) \Phi_{i}(\lambda) d \lambda$,

where $F(\lambda)$ is the actinic flux, $\sigma_{i}(\lambda)$ is the absorption cross section, $\Phi_{i}(\lambda)$ is the quantum yield, and $\lambda$ is the wavelength. $\sigma_{i}(\lambda)$ and $\Phi_{i}(\lambda)$ are unique to reactions and species. However, dust can affect the actinic flux through absorption and scattering.

An online photolysis module is incorporated in CMAQ 5.0 , which allows the calculation of actinic fluxes and photolysis rates for each grid at each time step based on the changes in particle concentrations (Binkowski et al., 2007). In this study, the impacts of dust on photolysis chemistry through their effects on the actinic flux are analyzed by comparing the results of DUST_REVISED with that of DUST_OFF. 
(a) The $\mathrm{NO}_{2}$ photolysis rate

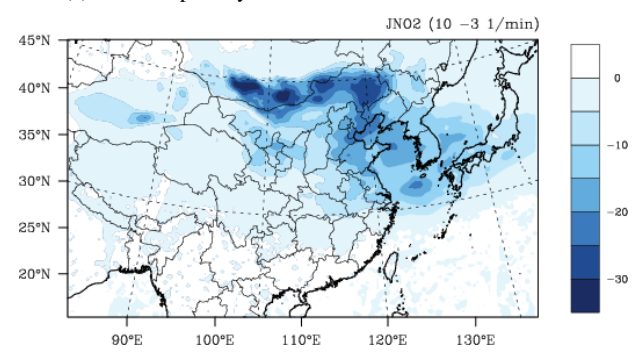

(b) $\mathrm{The}_{3}$ photolysis rate

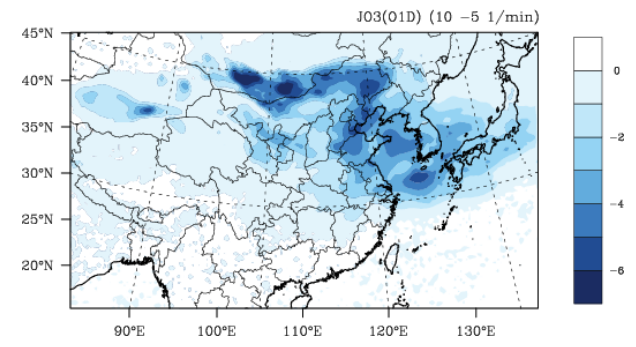

Fig. 11. The average differences of the photolysis rates simulated by DUST_REVISED and DUST_OFF, April 28 to May 6.

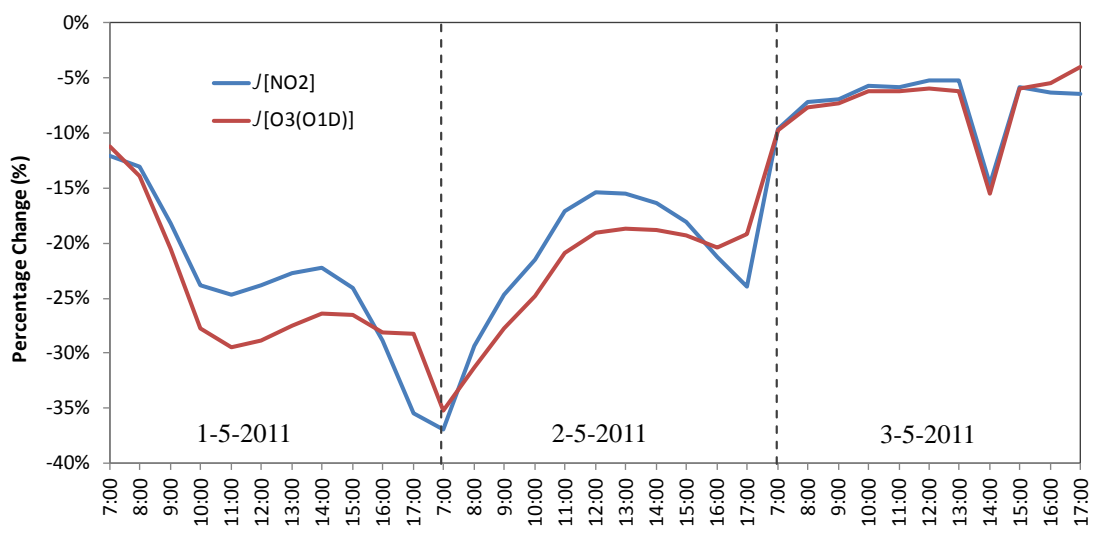

Fig. 12. Diurnal cycle of the percentage change of the $\mathrm{NO}_{2}$ photolysis rate and the $\mathrm{O}_{3}$ photolysis rate in Shanghai, 1 to May 3 .

There are two important photolysis rates affecting tropospheric ozone photochemistry, (1) the $\mathrm{NO}_{2}$ photolysis $\left(J\left[\mathrm{NO}_{2}\right]\right)$ to form the ground state oxygen atom $\mathrm{O}\left({ }^{3} \mathrm{P}\right)$ and (2) the $\mathrm{O} 3$ photolysis $\left(\mathrm{J}\left[\mathrm{O}_{3}\left(\mathrm{O}^{1} \mathrm{D}\right)\right]\right.$ ) to form the electronically excited $\mathrm{O}\left({ }^{1} \mathrm{D}\right)$ atom ( $\mathrm{Li}$ et al., 2011):

$$
\begin{aligned}
& \mathrm{O}_{3}+h v \longrightarrow \mathrm{O}_{2}+\mathrm{O}\left({ }^{1} \mathrm{D}\right) \\
& \mathrm{NO}_{2}+h v \longrightarrow \mathrm{NO}+\mathrm{O}\left({ }^{3} \mathrm{P}\right)
\end{aligned}
$$

As shown in Fig. 11, the $\mathrm{NO}_{2}$ photolysis $\left(J\left[\mathrm{NO}_{2}\right]\right)$ and the $\mathrm{O} 3$ photolysis $\left(J\left[\mathrm{O}_{3}\left(\mathrm{O}^{1} \mathrm{D}\right)\right]\right)$ are respectively reduced by about $2.4 \%$ and $1.9 \%$, on average, in domain 1 during 28 April to 6 May. The perturbations are mainly in dust source regions and along the dust transport path, which are similar to the distribution of irradiance changes.

Figure 12 shows the diurnal variation of the percentage change of $J\left[\mathrm{NO}_{2}\right]$ and $J\left[\mathrm{O}_{3}\left(\mathrm{O}^{1} \mathrm{D}\right)\right]$ in Shanghai, which is in the YRD region. The reduction of $J\left[\mathrm{NO}_{2}\right]$ and $J\left[\mathrm{O}_{3}\left(\mathrm{O}^{1} \mathrm{D}\right)\right]$ due to dust is significant in the early morning of 2 May, nearly $-40 \%$. Besides the impacts of high dust concentration, these significant reductions also indicate the effect of a long aerosol optical path for incoming radiation when the solar zenith angle (SZA) is large in the morning ( $\mathrm{Li}$ et al., 2011).

\section{Concentrations of $\mathrm{O}_{3}$ and $\mathrm{OH}$}

The photolysis frequencies of $J\left[\mathrm{O}_{3}\left(\mathrm{O}^{1} \mathrm{D}\right)\right]$ and $J\left[\mathrm{NO}_{2}\right]$ play a key role in the formation of $\mathrm{O}_{3}$ and $\mathrm{OH}$ in the troposphere through the following reactions:

$$
\begin{aligned}
& \mathrm{NO}_{2}+h v \longrightarrow \mathrm{NO}+\mathrm{O}\left({ }^{3} \mathrm{P}\right) \\
& \mathrm{O}\left({ }^{3} \mathrm{P}\right)+\mathrm{O}_{2}+M \longrightarrow \mathrm{O}_{3}+M \\
& \mathrm{O}_{3}+h v \longrightarrow \mathrm{O}_{2}+\mathrm{O}\left({ }^{1} \mathrm{D}\right) \\
& \mathrm{O}\left({ }^{1} \mathrm{D}\right)+\mathrm{H}_{2} \mathrm{O} \longrightarrow 2 \mathrm{OH} \\
& \mathrm{OH}+\mathrm{VOCs}+\mathrm{O}_{2} \longrightarrow \mathrm{RO}_{2} \\
& \mathrm{RO}_{2}+\mathrm{NO} \longrightarrow \mathrm{RO}+\mathrm{NO}_{2}
\end{aligned}
$$

The simulation results show that the surface $\mathrm{O}_{3}$ concentrations reduced about $1.5 \%$, on average, for domain 1 and the maximum reached 6 ppbv due to the dust storm. Figure 13a shows that the largest perturbations of $\mathrm{O}_{3}$ occurred in a region that included the China Sea, eastern China and Korea. One major reason is that the air mass with dust remained over this region for two days (2-3 May, as shown in Fig. 8) due to the high pressure control. The average decrease of $\mathrm{OH}$ was about $3.1 \%$ overall in domain 1 , resulting from the reductions in $\mathrm{O}\left({ }^{1} \mathrm{D}\right)$ generated by ultraviolet photolysis of $\mathrm{O}_{3}$ (Bian and Zender, 2003). As shown in Fig. 13b, the reduction of $\mathrm{OH}$ concentrations is correlated with the spatial distribution of $J\left[\mathrm{NO}_{2}\right]$ reduction due to the short chemical lifetime of $\mathrm{OH}$. For the YRD region, because of the reduction of local generation and long transport, the $\mathrm{O}_{3}$ and $\mathrm{OH}$ 
(a) $\mathrm{O}_{3}$ concentrations

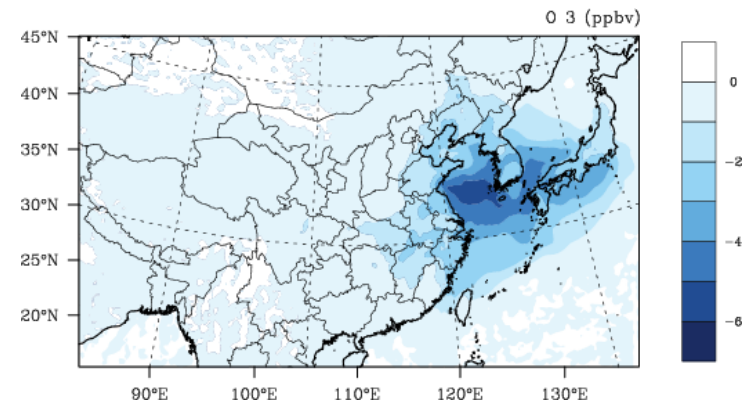

(b) OH concentrations

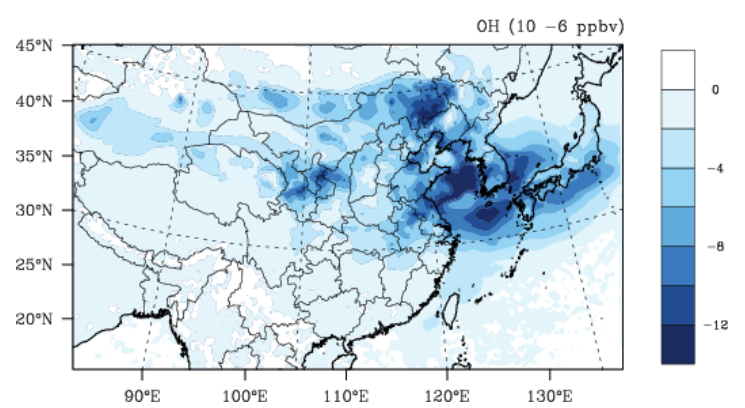

Fig. 13. The average differences between the simulations in the surface layer by DUST_REVISED and DUST_OFF, 28 April to 6 May. (a) $\mathrm{O}_{3}$ concentrations; $(\mathbf{b}) \mathrm{OH}$ concentrations.

concentrations respectively decreased by $9.4 \%$ and $12.1 \%$, on average. These values are comparable with those reported by Ying et al. (2011), in which the $\mathrm{O}_{3}$ reduction in Mexico City dipped to 10ppbv and the reduction of $\mathrm{OH}$ was 5-20\% during a dust event. The change of $\mathrm{O}_{3}$ and $\mathrm{OH}$ level can further affect the formation of secondary aerosols in the atmosphere by changing the oxidation rate of their precursors. For example, nitrate particles and sulfate particles may decrease because of the lessening in conversion of $\mathrm{HNO}_{3}$ from $\mathrm{NO}_{2}$ reaction with $\mathrm{OH}$, and $\mathrm{H}_{2} \mathrm{SO}_{4}$ from $\mathrm{SO}_{2}$ reaction with $\mathrm{OH}$ and $\mathrm{O}_{3}$.

\section{Conclusions}

In this study, we analyzed a dust event in 2011 with the CMAQ5.0 coupled with an in-line windblown dust model. The threshold friction velocity for loose, fine-grained soil with low surface roughness in the dust model was revised according to Chinese monitoring data. The predictions of the model DUST-REVISED agreed well with the observations.

This dust storm broke out in Xinjiang and Mongolia during 28 to 30 April, 2011. Dust particles were transported a long distance and the impacts even spread to the YRD region. On 1 May, the $\mathrm{PM}_{10}$ concentration in the YRD region began to increase, reaching a maximum $1000 \mu \mathrm{g} \mathrm{m}^{-3}$. The large amount of dust particles carrying fungal spores, microorganisms and anthropogenic pollutants during transport posed a serious threat to public health. In such a densely populated region, the human health loss can be quite serious. The dust particles also had significant impacts on the optical/radiative characteristics by absorption and scattering. The visibility decreased to below $3 \mathrm{~km}$ during the dust event, which impairs road and air transportation. The hourly averaged simulation results showed that in Shanghai, the largest perturbations of AOD and irradiance were about $0.8 \mathrm{DU}$ and $-130 \mathrm{~W} \mathrm{~m}^{-2}$, respectively. The decrease of actinic fluxes further impacts the photochemistry in this region. In Shanghai, the negative effects on the $\mathrm{NO}_{2}$ and $\mathrm{O}_{3}$ photolysis were $-35 \%$ when dust particles arrived. For the YRD region, because of the reduc- tion of local generation and reduction of long-range transport, the $\mathrm{O}_{3}$ and $\mathrm{OH}$ concentrations decreased by $9.4 \%$ and $12.1 \%$, respectively. Such changes in $\mathrm{O}_{3}$ and $\mathrm{OH}$ levels can further affect the formation of secondary aerosols in the atmosphere by their direct determining effects on the oxidation rates of their precursors. For example, nitrate particles and sulfate particles can decrease due to the lessening in conversion of $\mathrm{HNO}_{3}$ from $\mathrm{NO}_{2}$ reaction with $\mathrm{OH}$, and $\mathrm{H}_{2} \mathrm{SO}_{4}$ from $\mathrm{SO}_{2}$ reaction with $\mathrm{OH}$ and $\mathrm{O}_{3}$.

Research on the dust pollution is an important work and modeling is a useful method. CMAQ is a widely used air quality model and the revision of parameters for the dust emission model is meaningful for an effective CMAQ application. Further studies that include more accurate particle size distributions of dust emissions, heterogeneous reactions on the surface of dust particles, and the interaction between dust particle and meteorological parameters shall be conducted to improve the understanding of dust impacts on air quality. The $\mathrm{PM}_{2.5} / \mathrm{PM}_{10}$ ratio for dust emission is a fixed value in the current model. However, in actuality, it may be affected by soil texture, wind speed, and so on. Additionally, the current CMAQ version does not consider some important heterogeneous reactions on the surface of dust particles, such as $\mathrm{SO}_{2}, \mathrm{O}_{3}$, and $\mathrm{H}_{2} \mathrm{O}_{2}$, which might also be an important contributors to the impacts of dust on pollutant concentration. In future studies more heterogeneous reactions shall be coupled into the model. We also did not consider the effects through the feedbacks of dust on meteorology in this study. It will be meaningful to consider these effects by running the two-way coupled WRF-CMAQ modeling system in the future.

\section{Supplementary material related to this article is available online at http://www.atmos-chem-phys.net/14/ 1239/2014/acp-14-1239-2014-supplement.pdf.}


Acknowledgements. This work was sponsored by the National Natural Science Foundation of China (21221004), Strategic Priority Research Program of the Chinese Academy of Sciences (XBD05020300), and the special fund of State Key Joint Laboratory of Environment Simulation and Pollution Control (12L05ESPC). The corresponding author, Shuxiao Wang, is supported by the Program for New Century Excellent Talents in University (NCET-10-0532) and the China Scholarship Council. The authors also very much appreciate the help on CMAQ5.0 from David Wong at the US Environmental Protection Agency and the help on the dust emission module in CMAQ5.0 from Daniel Q. Tong at the US National Oceanic and Atmospheric Administration (NOAA).

Edited by: K. Schaefer

\section{References}

Ault, A. P., Williams, C. R., White, A. B., Neiman, P. J., Creamean, J. M., Gaston, C. J., Ralph, F. M., and Prather, K. A.: Detection of Asian dust in California orographic precipitation, J. Geophys. Res.-Atmos., 116, D16205, doi:10.1029/2010JD015351, 2011.

Baker: Meteorological Modeling Protocol for Application to $\mathrm{PM}_{2.5}$ /haze/ozone Modeling Projects, 2004.

Bian, H. S., and Zender, C. S.: Mineral dust and global tropospheric chemistry: Relative roles of photolysis and heterogeneous uptake, J. Geophys. Res.-Atmos., 108, 4672, doi:10.1029/2002jd003143, 2003.

Binkowski, F. S., Arunachalam, S., Adelman, Z., and Pinto, J. P.: Examining photolysis rates with a prototype Online photolysis module in CMAQ, Journal of Applied Meteorology and Climatology, 46, 1252-1256, doi:10.1175/jam2531.1, 2007.

Doney, S. C., Mahowald, N., Lima, I., Feely, R. A., Mackenzie, F. T., Lamarque, J.-F., and Rasch, P. J.: Impact of anthropogenic atmospheric nitrogen and sulfur deposition on ocean acidification and the inorganic carbon system, Proc. Natl. Acad. Sci. USA, 104, 14580-14585, doi:10.1073/pnas.0702218104, 2007.

Emery, C., Tai, E., Yarwood, G.: Enhanced meteorological modeling and performance evaluation for two texas episodes. Report to the Texas Natural Resources Conservation Commission, ENVIRON, International Corp, Novato, CA, 2001.

Evans, B. T. N. and Fournier, G. R.: Simple approximation to extinction efficiency valid over all size parameters, Appl. Optics, 29, 4666-4670, 1990.

Fan, J.-1., Hu, Z. Y., Wang, T. J., and Zhou, J.: Dynamics of dry deposition velocities of atmospheric nitrogen compounds in a broadleaf forestland, China Environ. Sci., 29, 574-577, 2009.

Fan, Q., Shen, C., Wang, X. M., Li, Y., Huang, W., Liang, G. X., Wang, S. Y., and Huang, Z. E.: Impact of a dust storm on characteristics of particle matter (PM) in Guangzhou, China, AsiaPac. J. Atmos. Sci., 49, 121-131, doi:10.1007/s13143-013-00132, 2013.

Forster, P., Artaxo, P., Berntsen, T., Betts, R., et al.: Changes in atmospheric constituents and in radiative forcing. In: Climate Change 2007: The Physical Science Basis. Contribution of Working Group I to the Fourth Assessment Report of the Intergovernmental Panel on Climate Change, edited by: Solomon, S., Qin, D., Manning, M., Chen, Z., Marquis, M., Avert, K. B., Tig- nor, M., and Miller, H. L., Cambridge University Press, Cambridge, UK and New York, NY, USA, 2007.

Fountoukis, C. and Nenes, A.: ISORROPIA II: a computationally efficient thermodynamic equilibrium model for $\mathrm{K}^{+}$$\mathrm{Ca}^{2+}-\mathrm{Mg}^{2+}-\mathrm{NH}_{4}^{+}-\mathrm{Na}^{+}-\mathrm{SO}_{4}^{2-}-\mathrm{NO}_{3-}-\mathrm{Cl}^{-}-\mathrm{H}_{2} \mathrm{O}$ aerosols, Atmos. Chem. Phys., 7, 4639-4659, doi:10.5194/acp-7-4639-2007, 2007.

Fu, H., Zhang, M., Li, W., Chen, J., Wang, L., Quan, X., and Wang, W.: Morphology, composition and mixing state of individual carbonaceous aerosol in urban Shanghai, Atmos. Chem. Phys., 12, 693-707, doi:10.5194/acp-12-693-2012, 2012.

Fu, Q., Zhuang, G., Li, J., Huang, K., Wang, Q., Zhang, R., Fu, J., Lu, T., Chen, M., Wang, Q., Chen, Y., Xu, C., and Hou, B.: Source, long-range transport, and characteristics of a heavy dust pollution event in Shanghai, J. Geophys. Res.-Atmos., 115, D00K29, doi:10.1029/2009JD013208, 2010.

Fu, X., Wang, S. X., Zhao, B., Xing, J., Cheng, Z., Liu, H., and Hao, J. M.: Emission inventory of primary pollutants and chemical speciation in 2010 for the Yangtze River Delta region, China, Atmos. Environ., 70, 39-50, doi:10.1016/j.atmosenv.2012.12.034, 2013.

Geng, H., Park, Y., Hwang, H., Kang, S., and Ro, C.-U.: Elevated nitrogen-containing particles observed in Asian dust aerosol samples collected at the marine boundary layer of the Bohai Sea and the Yellow Sea, Atmos. Chem. Phys., 9, 6933-6947, doi:10.5194/acp-9-6933-2009, 2009.

Gillette, D., J. Adams, A. Endo, D. Smith, and R. Kihl.: Threshold Velocities for Input of Soil Particles Into the Air by Desert Soils, J. Geophys. Res., 85, 5621-5630, 1980.

Guenther, A., Karl, T., Harley, P., Wiedinmyer, C., Palmer, P. I., and Geron, C.: Estimates of global terrestrial isoprene emissions using MEGAN (Model of Emissions of Gases and Aerosols from Nature), Atmos. Chem. Phys., 6, 3181-3210, doi:10.5194/acp-63181-2006, 2006.

Han, X., Ge, C., Tao, J. H., Zhang, M. G., and Zhang, R. J.: Air Quality Modeling for a Strong Dust Event in East Asia in March 2010, Aerosol Air Qual. Res., 12, 615-628, doi:10.4209/aaqr.2011.11.0191, 2012.

Han, Z. W., Ueda, H., Matsuda, K., Zhang, R. J., Arao, K., Kanai, Y., and Hasome, H.: Model study on particle size segregation and deposition during Asian dust events in March 2002, J. Geophys. Res.-Atmos., 109, D19205, doi:10.1029/2004JD004920, 2004.

Huang, K., Zhuang, G., Li, J., Wang, Q., Sun, Y., Lin, Y., and Fu, J. S.: Mixing of Asian dust with pollution aerosol and the transformation of aerosol components during the dust storm over China in spring 2007, J. Geophys. Res.-Atmos., 115, D00k13, doi:10.1029/2009jd013145, 2010.

Huang, K., Zhuang, G., Lin, Y., Fu, J. S., Wang, Q., Liu, T., Zhang, R., Jiang, Y., Deng, C., Fu, Q., Hsu, N. C., and Cao, B.: Typical types and formation mechanisms of haze in an Eastern Asiamegacity, Shanghai, Atmos. Chem. Phys., 12, 105-124, doi:10.5194/acp-12-105-2012, 2012.

Ichinose, T., Yoshida, S., Hiyoshi, K., Sadakane, K., Takano, H., Nishikawa, M., Mori, I., Yanagisawa, R., Kawazato, H., Yasuda, A., and Shibamoto, T.: The effects of microbial materials adhered to Asian sand dust on allergic lung inflammation, Arch. Environ. Cont. Toxicol., 55, 348-357, doi:10.1007/s00244-0079128-8, 2008. 
Kain, J. S.: The Kain-Fritsch convective parameterization: An update, Journal of Applied Meteorology, 43, 170181, doi:10.1175/1520-0450(2004)043<0170:tkcpau>2.0.CO;2, 2004.

Kang, J. H., Liu, T. C., Keller, J., and Lin, H. C.: Asian dust storm events are associated with an acute increase in stroke hospitalisation, J. Epidemiol. Comm. Health, 67, 125-131, doi:10.1136/jech-2011-200794, 2013.

Knipping, E. M., Kumar, N., Pun, B. K., Seigneur, C., Wu, S. Y., and Schichtel, B. A.: Modeling regional haze during the BRAVO study using CMAQ-MADRID: 2. Source region attribution of particulate sulfate compounds, J. Geophys. Res.-Atmos., 111, D06303, doi:10.1029/2004JD005609, 2006.

Kumar, R., Srivastava, S. S., and Kumari, K. M.: Modeling dry deposition of $\mathrm{S}$ and $\mathrm{N}$ compounds to vegetation, Ind. J. Radio Space Phys., 37, 272-278, 2008.

Lee, S., Choi, B., Yi, S. M., and Ko, G.: Characterization of microbial community during Asian dust events in Korea, Sci. Total Environ., 407, 5308-5314, doi:10.1016/j.scitotenv.2009.06.052, 2009.

Li, G., Bei, N., Tie, X., and Molina, L. T.: Aerosol effects on the photochemistry in Mexico City during MCMA2006/MILAGRO campaign, Atmos. Chem. Phys., 11, 51695182, doi:10.5194/acp-11-5169-2011, 2011.

Li, W. Y., Shen, Z. B, Lu, S. H., and Li, Y. H: Sensitivity Tests of Factors Influencing Wind Erosion, J. Desert Res., 27, 984-993, 2007.

Lin, C. Y., Chou, C. C. K., Wang, Z. F., Lung, S. C., Lee, C. T., Yuan, C. S., Chen, W. N., Chang, S. Y., Hsu, S. C., Chen, W. C., and Liu, S. C.: Impact of different transport mechanisms of Asian dust and anthropogenic pollutants to Taiwan, Atmos. Environ., 60, 403-418, doi:10.1016/j.atmosenv.2012.06.049, 2012.

Mlawer, E. J. and Clough, S. A.: Shortwave Clear-Sky ModelMeasurement Intercomparison Using RRTM, the 8th Atmospheric Radiation Measurement (ARM) Science Team Meeting, Tucson, Arizona, USA, 1998.

Mlawer, E. J., Taubman, S. J., Brown, P. D., Iacono, M. J., and Clough, S. A.: Radiative transfer for inhomogeneous atmospheres: RRTM, a validated correlated-k model for the longwave, J. Geophys. Res.-Atmos., 102, 16663-16682, doi:10.1029/97jd00237, 1997.

Morrison, H., Thompson, G., and Tatarskii, V.: Impact of Cloud Microphysics on the Development of Trailing Stratiform Precipitation in a Simulated Squall Line: Comparison of One- and Two-Moment Schemes, Mon. Weather Rev., 137, 991-1007, doi:10.1175/2008mwr2556.1, 2009.

National Bureau of Statistics of China: China Statistical Yearbook 2011, China Statistics Press, Beijing, 2011a.

National Bureau of Statistics of China: China Energy Statistical Yearbook 2011, China Statistics Press, Beijing, 2011b.

Niu, S. J. and Sun, Z. B.: Aircraft observation of spatial and temporal characteristics of desert dust aerosol and $\mathrm{PM}_{2.5}$ Annual Meeting of Chinese Meteorological Society Beijing, 55-56-5758, 2003.

Park, S. U., Choe, A., and Park, M. S.: A simulation of Asian dust events observed from 20 to 29 December 2009 in Korea by using ADAM2, Asia-Pac. J. Atmos. Sci., 49, 95-109, doi:10.1007/s13143-013-0011-4, 2013.
Philip J. C.: Incorporation of Non-Linear Effective Cross-Section Parameterizations into a Fast Photolysis Computation Code (Fast-J), J. Atmos. Chem., 37, 283-297, 2000.

Pleim, J. E.: A combined local and nonlocal closure model for the atmospheric boundary layer. Part I: Model description and testing, J. Appl. Meteorol. Climatol., 46, 1383-1395, doi:10.1175/jam2539.1, 2007.

Rind, D., Chin, M., Feingold, G., Streets, D., Kahn, R. A.,Schwartz, S. E., and Yu, H.: Modeling the effects of aerosolson climate, in atmospheric aerosol properties and climate impacts, A Report by the US Climate Change Science Program andthe Subcommittee on Global Change Research, edited by: Chin, M., Kahn, R. A., and Schwartz, S. E., National Aeronautics and Space Administration, Washington, DC, USA, 2009.

Shi, J. H., Gao, H. W., Zhang, J., Tan, S. C., Ren, J. L., Liu, C. G., Liu, Y., and Yao, X.: Examination of causative link between a spring bloom and dry/wet deposition of Asian dust in the Yellow Sea, China, J. Geophys. Res.-Atmos., 117, D17304, doi:10.1029/2012jd017983, 2012.

Simon, H. and Bhave, P. V.: Simulating the Degree of Oxidation in Atmospheric Organic Particles, Environ. Sci. Technol., 46, 331339, doi:10.1021/es202361w, 2012.

Smoydzin, L., Teller, A., Tost, H., Fnais, M., and Lelieveld, J.: Impact of mineral dust on cloud formation in a Saharan outflow region, Atmos. Chem. Phys., 12, 11383-11393, doi:10.5194/acp12-11383-2012, 2012.

Sokolik, I. N., Winker, D. M., Bergametti, G., Gillette, D. A., Carmichael, G., Kaufman, Y. J., Gomes, L., Schuetz, L., and Penner, J. E.: Introduction to special section: Outstanding problems in quantifying the radiative impacts of mineral dust, J. Geophys. Res.-Atmos., 106, 18015-18027, doi:10.1029/2000jd900498, 2001.

Solomos, S., Kushta, J., and Kallos, G.: Effects of Airborne Particles on Cloud Formation and Precipitation: A Modeling Study, in: Air Pollution Modeling and Its Application XXI, edited by: Steyn, D. G., and Castelli, S. T., NATO Science for Peace and Security Series C-Environmental Security, 571-578, 2012.

Streets, D. G., Bond, T. C., Carmichael, G. R., Fernandes, S. D., Fu, Q., He, D., Klimont, Z., Nelson, S. M., Tsai, N. Y., Wang, M. Q., Woo, J. H., and Yarber, K. F.: An inventory of gaseous and primary aerosol emissions in Asia in the year 2000, J. Geophys. Res.-Atmos., 108, 8809, doi:10.1029/2002jd003093, 2003.

Sun, H., Pan, Z., and Liu, X.: Numerical simulation of spatialtemporal distribution of dust aerosol and its direct radiative effects on East Asian climate, J. Geophys. Res.-Atmos., 117, D13206, doi:10.1029/2011jd017219, 2012.

Tong, D. Q., Bowker, G. E., He, S., Byun, D. W., Mathur, R., Gillette, D. A.: Development of a Windblown Dust Module within the Community Multi-scale Air Quality (CMAQ) Model: Description and Preliminary Applications in the Continental United States, submitted, J. Geophys. Res., 2011.

Wang, H., Zhang, X. Y., Gong, S. L., Chen, Y., Shi, G. Y., and Li, W.: Radiative feedback of dust aerosols on the East Asian dust storms, J. Geophys. Res.-Atmos., 115, D23214, doi:10.1029/2009jd013430, 2010a.

Wang, K., Zhang, Y., Nenes, A., and Fountoukis, C.: Implementation of dust emission and chemistry into the Community Multiscale Air Quality modeling system and initial application to 
an Asian dust storm episode, Atmos. Chem. Phys., 12, 1020910237, doi:10.5194/acp-12-10209-2012, 2012a.

Wang, L. T., Jang, C., Zhang, Y., Wang, K., Zhang, Q., Streets, D., Fu, J., Lei, Y., Schreifels, J., He, K., Hao, J., Lam, Y.-F., Lin, J., Meskhidze, N., Voorhees, S., Evarts, D., and Phillips, S.: Assessment of air quality benefits from national air pollution control policies in China. Part I: Background, emission scenarios and evaluation of meteorological predictions, Atmos. Environ., 44, 3442-3448, doi:10.1016/j.atmosenv.2010.05.051, 2010 b.

Wang, L. T., Xu, J., Yang, J., Zhao, X., Wei, W., Cheng, D., Pan, $\mathrm{X}$., and $\mathrm{Su}, \mathrm{J}$. : Understanding haze pollution over the southern Hebei area of China using the CMAQ model, Atmos. Environ., 56, 69-79, doi:10.1016/j.atmosenv.2012.04.013, 2012b.

Wang, S. X., Zhao, M., Xing, J., Wu, Y., Zhou, Y., Lei, Y., He, K., Fu, L., and Hao, J.: Quantifying the Air Pollutants Emission Reduction during the 2008 Olympic Games in Beijing, Environ. Sci. Technol., 44, 2490-2496, doi:10.1021/es9028167, 2010c.

Whitten, G. Z., Heo, G., Kimura, Y., McDonald-Buller, E., Allen, D. T., Carter, W. P. L., and Yarwood, G.: A new condensed toluene mechanism for Carbon Bond CB05-TU, Atmos. Environ., 44, 5346-5355, doi:10.1016/j.atmosenv.2009.12.029, 2010.

Xiu, A. J. and Pleim, J. E.: Development of a land surface model. Part I: Application in a mesoscale meteorological model, Journal of Applied Meteorology, 40, 192-209, doi:10.1175/15200450(2001)040<0192:doalsm>2.0.CO;2, 2001.
Yan, H., Gao, H., Yao, X., and Wang, Z.: Simulating dry deposition fluxes of $\mathrm{PM}_{10}$ and particulate inorganic nitrogen over the eastern China seas during a severe Asian dust event using WRF-Chem model, J. Ocean Univ. China, 11, 301-314, doi:10.1007/s11802-012-1857-2, 2012.

Ying, Z., Tie, X., Madronich, S., Li, G., and Massie, S.: Simulation of regional dust and its effect on photochemistry in the Mexico City area during MILAGRO experiment, Atmos. Environ., 45, 2549-2558, doi:10.1016/j.atmosenv.2011.02.018, 2011.

Zender, C. S., Bian, H. S., and Newman, D.: Mineral Dust Entrainment and Deposition (DEAD) model: Description and 1990s dust climatology, J. Geophys. Res.-Atmos., 108, 4416, doi:10.1029/2002JD002775, 2003.

Zhang, X. Y., Gong, S. L., Zhao, T. L., Arimoto, R., Wang, Y. Q., and Zhou, Z. J.: Sources of Asian dust and role of climate change versus desertification in Asian dust emission, Geophys. Res. Lett., 30, 2272, doi:10.1029/2003g1018206, 2003.

Zhang, Y., Liu, P., Pun, B., and Seigneur, C.: A comprehensive performance evaluation of MM5-CMAQ for the Summer 1999 Southern Oxidants Study episode - Part I: Evaluation protocols, databases, and meteorological predictions, Atmos. Environ., 40, 4825-4838, doi:10.1016/j.atmosenv.2005.12.043, 2006.

Zhao, B., Wang, S. X., Wang, J. D., Fu, J., Liu, T. H., Xu, J. Y., $\mathrm{Fu}, \mathrm{X}$., Hao, J. M.: Impact of national $\mathrm{NO}_{\mathrm{X}}$ and $\mathrm{SO}_{2}$ emission control policies on particulate matter pollution in China, Atmos. Environ., 77, 453-463, 2013. 